No 4069

Studia nad Autorytaryzmem i Totalitaryzmem 43, nr 2

Wrocław 2021

https://doi.org/10.19195/2300-7249.43.2.10

ADAM WIELOMSKI

ORCID: 0000-0001-8692-6469

Uniwersytet Kardynała Stefana Wyszyńskiego

a.wielomski@uksw.edu.pl

\title{
Istota totalitaryzmu. Wokół teorii Zbigniewa Brzezińskiego i Carla Friedricha
}

Słowa kluczowe: Zbigniew Brzeziński, totalitaryzm, Związek Radziecki, Trzecia Rzesza.

\author{
THE ESSENCE OF TOTALITARIANISM: \\ ON ZBIGNIEW BRZEZIŃSKI AND CARL FRIEDRICH'S THEORY
}

\begin{abstract}
The aim of this text is a contemporary estimation of the thesis formed in a famous book by Zbigniew Brzeziński and Carl Friedrich, Totalitarian Dictatorship and Autocracy (1956). This is a classic text of Western political science about totalitarianism, simultaneously scientific and political. Scientific, because it presents the idea of three types of political regimes in the 20th century: totalitarian, authoritarian, and liberal-democratic. Political, because the term "totalitarianism" was very useful in the time of the Cold War. This term presents the old (Nazi Germany) and new (Stalinist Russia) totalitarian states as equal political enemies of the USA, equal in their hostility to political and individual freedom, i.e. America's creed. By using this term, the Americans can create a horrible picture of Russian communism as totalitarian, the same as Hitler's regime, while presenting old enemies (West Germany, Italy, and Japan) as good friends of both the USA and freedom, because in this moment these states are democratic and liberal. The new term ended the old line of the delimitation between fascist or pro-fascist and antifascist states and legitimates the new alliance between the USA and Franco's Spain. The author analyses the definition of totalitarianism by Brzeziński and Friedrich as well as the political and ideological accusations made against this book by leftist critics.
\end{abstract}

Keywords: Zbigniew Brzeziński, totalitarianism, Soviet Union, Third Reich. 


\section{Uwagi wstępne i cel badawczy}

Celem tego artykułu jest ocena analizy pojęcia totalitaryzmu, która wyszła spod piór Zbigniewa Brzezińskiego i Carla Friedricha w postaci głośnej swego czasu rozprawy Dyktatura totalitarna i autokracja (ang. Totalitarian Dictatorship and Autocracy, 1956) ${ }^{1}$. Chcemy pracę tę — wydaną ponad sześćdziesiąt lat temu - ocenić z perspektywy późniejszych badań nad ideologią, teorią państwa i prawa państw totalitarnych. Uznając ją za klasyczną dla nauk politycznych lat pięćdziesiątych XX wieku, będziemy starali się pokazać główne linie polemik wokół tytułowego problemu, które rozpowszechniły się w następnych dziesięcioleciach. W końcu chcemy odpowiedzieć na pytanie: na ile monografia ta zachowała wartość dla współczesnych badaczy? Czy warto ją jeszcze czytać, czy też jej tezy zostały już dawno temu obalone w literaturze przedmiotu?

Zanim jednakże przejdziemy do realizacji wskazanych powyżej celów, musimy poczynić dwie uwagi:

1. Kwestia autorstwa. Dyktatura totalitarna i autokracja została napisana przez Zbigniewa Brzezińskiego wespół z Carlem Friedrichem, o czym dość rzadko się dziś pamięta, szczególnie w Polsce, ponieważ Brzeziński - jako polityk i politolog — zdecydowanie przerósł współautora książki. Ten drugi jest w naszym kraju całkowicie nieznany ${ }^{2}$. Jednakże biorąc pod uwagę, że w momencie publikacji książki Friedrich miał 57, zaś Brzeziński tylko 28 lat, można założyć, że udział tego pierwszego w pracy nad książką był dominujący. Wskazuje na to nie tylko wiek i dotychczasowy dorobek obydwu badaczy, lecz i to, że na okładce nazwisko Friedricha znajduje się przed Brzezińskim, czyli wbrew zwyczajowej kolejności alfabetycznej. Jednakże autorzy książki nie zaznaczyli, które fragmenty zostały napisane przez którego z nich, w związku z czym będziemy traktowali tę monografię jako wspólną, skoro obydwaj w równej mierze wzięli odpowiedzialność za każdą zawartą w niej myśl.

2. Badany materiał. Interesująca nas monografia poświęcona została tytułowemu totalitaryzmowi. Pod pojęciem tym Friedrich i Brzeziński rozumieli: narodowy socjalizm w Niemczech, faszyzm we Włoszech, stalinizm radziecki i w krajach bloku wschodniego, a także maoizm w Chinach, przy czym dominuje tematyka nazistowska i stalinizm. Wiedza naszych autorów o totalitarnych Włoszech i Chinach jest raczej skromna. Główne tezy zostały postawione na podstawie przypadków niemieckiego i radzieckiego. Poza tym badacze ci mają problem z klasyfikacją Włoch Benito Mussoliniego, które same ogłosiły się wprawdzie państwem totalitarnym,

${ }^{1}$ Na potrzeby tego tekstu posługiwać będziemy się wydaniem z 1966 roku, gdzie C.J. Friedrich samodzielnie o dekadę dalej dociągnął dzieje państw komunistycznych.

${ }^{2}$ Szerzej na temat osoby i idei C.J. Friedricha zob. na przykład K. von Beyme, A Founding Father of Comparative Politics: Carl Joachim Friedrich, [w:] Comparative European Politics. The Story of a Profession, red. H. Daalder, London 1997, s. 7-14; H.J. Lietzmann, Carl Joachim Friedrich (1901-1984). Leben — Werk — Wirkung, [w:] Klassiker der Politikwissenschaft, red. H.J. Lietzmann, W. Bleek, München 2005, s. 179-191. 
ale autonomiczne wobec monopartii pozostały monarchia, armia i Kościół katolicki, co ostatecznie umożliwiło spektakularne obalenie Duce w 1943 roku. Stąd też biorą się znane w literaturze wątpliwości, czy Włochy należy zaliczyć do grona państw totalitarnych ${ }^{3}$.

\section{Totalitaryzm i totalitaryzmy}

\subsection{Pojęcie totalitaryzmu}

Carl Friedrich i Zbigniew Brzeziński definiują państwo totalitarne jako państwo nowego typu, nieznane wcześniej w dziejach przed XX wiekiem. Podkreślają, że dyktatura totalitarna nie jest - a we wcześniejszej literaturze znajdujemy takie głosy ${ }^{4}$ - powrotem do osiemnastowiecznego absolutyzmu, do przedliberalnego świata sprzed rewolucji francuskiej. Przedrewolucyjny absolutyzm był rządem arystokratycznych elit, a nie wyrazem woli i emancypacji politycznej mas, czyli wielkich skupisk ludzkich powstałych w wyniku industrializacji, rewolucji przemysłowej i boomu demograficznego XIX stulecia ${ }^{5}$. Nasi autorzy widzą w totalitaryzmie jeden z wyrazów społeczeństwa masowego, które nie instytucjonalizuje się w postaci liberalnej demokracji. Totalitaryzm to specyficzna dwudziestowieczna dyktatura przenikająca całe społeczeństwo i wszystkie jednostki z osobna, dzięki nowoczesnym środkom komunikacji, kontroli, mediom, archiwom, nadzorowi tajnej policji, cenzurze, represjom itp. Dlatego „dyktatura totalitarna może zostać określona jako autokracja oparta na nowoczesnej technologii i masowej legitymizacji”'

Totalitaryzm to dyktatura wyposażona nie tylko w nowoczesną technikę, lecz także i w ideologię, którą Friedrich i Brzeziński definiują następująco:

Ideologia $[\ldots]$ to racjonalna piramida idei opisujących praktyczne środki zreformowania społeczeństwa w oparciu o mniejszy lub większy krytycyzm wobec społeczeństwa uprzednio już istniejącego. Gdy już się to [rewolucja, gwałtowna transformacja - przyp. A.W.] stanie, to ideologia poczyna bronić społeczeństwa, stając się defensywną i zawierającą opracowaną krytykę reformistycznych i rewolucyjnych ideologii?

${ }^{3}$ C.J. Friedrich, Z. Brzeziński, Totalitarian Dictatorship and Autocracy, New York 1966 [1956], s. 347-48. Kwestia ta do dziś wywołuje wielkie kontrowersje w literaturze przedmiotu. Najbardziej znani krytycy tezy o totalitaryzmie faszyzmu włoskiego to R. De Felice, Mussolini, Torino 1965-1997, t. 1-8; A. Aquarone, Fascismo e antifascismo nella storiografia italiana, Roma 1986. Argumenty obydwu stron sporu przedstawiają w skrócie: E. Gentile, La via italiana al totalitarismo, Roma 1995, s. 75-128 (interpretacja autorytarna); J.-Y. Darmagen, Logique du fascisme. L'Etat totalitaire en Italie, Paris 2008, s. 7-23 (interpretacja totalitarna).

${ }^{4}$ B. Lavergne, Les États totalitaires ou le retour de l'Europe au XVI ou XVII siècle [1937], [w:] Le totalitarisme. Le XX siècle en débat, red. E. Traverso, Paris 2001, s. 175-183.

5 C.J. Friedrich, Z. Brzeziński, op. cit., s. 3.

${ }^{6}$ Ibidem, s. 4.

7 Ibidem, s. 88. 
Ideologia totalitarna jest jednak szczególna w porównaniu z innymi, na przykład liberalizmem lub demokratycznym socjalizmem. Nasi autorzy określają ją mianem ,pseudo-religii” i widzą w niej negację liberalnej zasady rozdziału religii od państwa. Oto nowoczesny cezaropapizm. Jedynowładca w systemie ideologicznym, stanowiącym „substrat” religii, jest „władcą i arcykapłanem”, sprawującym „władzę hierokratyczną" siły i przemocy w stosunku do pogan (zwolenników innych idei) i heretyków (głoszących ideologię w odmiennej wersji).

W końcu Friedrich i Brzeziński wyliczają sześć cech charakterystycznych dla totalitaryzmu jako takiego, nie rozróżniając przy tym między komunizmem i narodowym socjalizmem:

1. Skonkretyzowana ideologia, stanowiąca oficjalny system doktrynalny opisujący wszystkie życiowe aspekty ludzkiej egzystencji, do której muszą się dostosować wszyscy żyjący w społeczeństwie, ostatecznie choćby biernie. Ideologia ta w sposób charakterystyczny jest skoncentrowana na projektowaniu końcowego stanu ludzkości. Słowem, zawiera element chiliastyczny, oparty na radykalnym odrzuceniu istniejącego społeczeństwa, proponując zdobycie świata dla nowego.

2. Masowa monopartia, zwykle kierowana jednoosobowo, przez „dyktatora”, a skupiająca stosunkowo niewielki procent całej populacji (tak do 10 procent) mężczyzn i kobiet, stanowiących rdzeń, którzy w sposób namiętny i bez wahania poświęcają się dla ideologii i wspierają każde działania mające na celu jej propagowanie. Partia tego typu ma charakter hierarchiczny, jest zorganizowana w sposób oligarchiczny, stoi ponad lub stanowi jedno z biurokracją rządową.

3. System terroru, tak fizycznego jak i psychicznego, pod kontrolą partii i tajnej policji, za pomocą którego przywódcy wspierają, ale i kontrolują partię. Cechą charakterystyczną jest to, że nie jest on skierowany wyłącznie przeciwko jawnym „wrogom” ustroju, ale także wobec mniej lub bardziej arbitralnie wybranym segmentom populacji. Terror tajnej policji i presja społeczna kierowana przez partię systematycznie używają zdobyczy nowoczesnej nauki, szczególnie zaś psychologii.

4. Warunkowany rozwojem technologicznym prawie całkowity monopol partii i rządu na wszystkie środki komunikacji masowej, takie jak prasa, radio i telewizja.

5. Podobnie warunkowany technicznie prawie całkowity monopol na posiadanie i używanie wszelkiej broni wojskowej.

6. Centralna kontrola i kierownictwo nad całą ekonomią za pomocą biurokratycznej koordynacji formalnie niezależnych firm, wraz ze znajdującymi się w nich związkami zawodowymi i innymi zorganizowanymi grupami społecznymi ${ }^{9}$.

Z dalszej lektury książki wyłaniają się także inne cechy charakterystyczne dla wszystkich omawianych systemów totalitarnych, choć autorzy nie uznali ich za na tyle istotne, aby wypunktować je w teoretycznym wstępie. Dopiszmy je więc za nich, kontynuując rozpoczętą numerację ${ }^{10}$ :

8 Ibidem, s. 6-7, 26, 33.

9 Ibidem, s. 22. W literaturze zauważono, że wyliczenie to stanowi rozwinięcie charakterystyki, którą C.J. Friedrich dwa lata wcześniej zawarł w tekście The unique character of totalitarian society, [w:] Totalitarianism, red. C.J. Friedrich, Cambridge 1954, s. 52-53.

10 C.J. Friedrich, Z. Brzeziński, op. cit., s. 199-200, 230-233 (industrializacja oparta na niewolnictwie); 247-252 (związki zawodowe); 279-295 (atomizacja); 205-212, 343-351 (rządy biurokracji); 353-354 (imperializm). 
7. Imperializm. Żadne państwo totalitarne nie jest zainteresowane utrzymaniem dotychczasowych granic, dążąc do stworzenia imperium. Włochy chcą odbudować Cesarstwo Rzymskie podbijając Etiopię, Bałkany, Algierię i Egipt; Niemcy zbudować rasowe imperium europejskie (Lebensraum); ZSRR zdobyć cały świat dla klasy robotniczej (internacjonalizm).

8. Forsowna industrializacja. Skoro systemy totalitarne mają cele imperialne i dążą do ekspansji zewnętrznej i budowy imperiów, to kładą w swoich systemach gospodarczych nacisk na rozbudowę przemysłu ciężkiego, produkującego nowoczesną broń. Industrializacja i zwiększenie produkcji przemysłowej w znacznej mierze opierają się na sile niewolniczej. Obozy koncentracyjne i gułagi to nowoczesne niewolnictwo, gdzie przetrzymywani tam ludzie za darmo karczują lasy, budują kanały i pracują na użytek przemysłu. Sam koszt utrzymania ich (na minimum egzystencji życiowej) i strażników czyni ich niewydajną pracę bardzo opłacalną, pozwalając szybko zwiększyć możliwości produkcyjne (Niemcy) lub dokonać industrializacji kraju dotąd rolniczego (ZSRR). Koncentracji kapitału na celach inwestycyjnych sprzyja także upartyjnienie związków zawodowych, które przestają walczyć o płace i warunki życia robotników, stając się narzędziem lepszej organizacji pracy, zwiększenia wydajności i indoktrynacji, czyli pełniąc rolę odwrotną od statutowej.

9. Atomizacja społeczna. Każda władza totalitarna za pomocą indoktrynacji, terroru, inwigilacji i przesiedleń dąży do zniszczenia społeczeństwa wspólnotowego i rozbicia go na zatomizowany thum jednostek, niezdolnych do samoorganizacji, w tym także do stawienia biernego lub czynnego oporu. Każdy boi się rozmawiać z każdym, gdyż panuje powszechny system donosicielstwa. Nikt nie wie, ilu ludzi myśli o systemie krytycznie, tak jak on sam. Ludzie obawiają się krytykować władzę na spotkaniu przyjaciół, a nawet w kręgu rodzinnym (casus Pawki Morozowa). W tej sytuacji opór ma charakter spontaniczny. Brak mu organizacji, co pozwala go łatwo stłumić (NRD 1953, Poznań 1956), o ile nie zostanie wsparty przez monopartię (Budapeszt 1956). Stąd wola zniszczenia kościołów, związków zawodowych, samorządności, rodziny (legalizacja rozwodów i aborcji), jak i rola pozaszkolnej organizacji życia dzieci i młodzieży poza domem przez organizacje kontrolowane przez partię.

10. Status wojska. Żaden z przywódców totalitarnych nie był generałem, który przeprowadził zamach stanu, stworzył monopartię i za jej pomocą zbudował totalitaryzm. Monopartia i jej ideologia zawsze stoją u genezy państwa totalitarnego. To partia drogą zamachu stanu (Włochy), wyborów (Niemcy) lub wojny domowej (Rosja, Chiny) zdobywa władzę. Dlatego wojsko i korpus oficerski są permanentnie podejrzane. Skoro generalicji nie sposób stworzyć polityczną decyzją, każąc dowodzić dywizjami generałom awansowanym z poruczników (o czym przekonał się Stalin w 1941 roku), to system musi korzystać z oficerów przedrewolucyjnych. Nie mając alternatywy, korzysta z ich doświadczenia, ale zarazem im nie ufa, ponieważ korpus oficerski — hierarchiczny i zdyscyplinowany — jest w państwie totalitarnym jedyną siłą autonomiczną, zdolną do ewentualnego buntu i skutecznego 
obalenia rządów partii. Dlatego oficerom bezustannie towarzyszy nadzór tajnej policji, oficerów politycznych itp.

11. Rządy biurokracji. Za fasadą rządów charyzmatycznej jednostki i rewolucyjnej ideologii (punkty 1-2) kryją się rządy biurokratów, złożone z oficjeli partyjnych, urzędników, oficerów służb. Dlatego w systemach totalitarnych, gdy tylko partia umocni swoją władzę, coraz mniej chodzi o rewolucję społeczną, ekonomiczną i kulturową, a o zachowanie władzy przez nowe elity administracyjne, dla których ideologia z czasem staje się systemem haseł i frazesów. Za rewolucyjną frazeologią kryją się interesy nowych elit, które pożądają władzy, dobrobytu, prestiżu, czyli dominuje chęć konserwatywnej afirmacji nowopowstałego status quo. Teza o totalitaryzmie jako wszechwładzy nad całym życiem społecznym i ekonomicznym partyjno-państwowej biurokracji za fasadą ideologii jest myślą przewodnią Dyktatury totalitarnej $i$ autokracji. Dlatego jest rzeczą dziwną, że punkt ten nie znalazł się pośród enumeracji immanentnych cech totalitaryzmu.

\subsection{Ideologie totalitarne}

Wyliczone powyżej punkty charakterystyczne dla wszystkich państw totalitarnych nie oznaczają, że totalitaryzmy nie różnią się między sobą. Przeciwnie, to, że Friedrich i Brzeziński wyliczyli tylko sześć (plus pięć wydedukowanych z ich rozprawy przez nas) cech wspólnych wskazuje, że w wielu miejscach systemy te są odmienne. Różnice między totalitaryzmami nie są znaczne co do organizacji państwa (co potem nazwano w politologii mianem „logiki totalitarnej”). Systemy te są sprzeczne w kwestiach ideologicznych, gdzie mamy radykalną opozycję pomiędzy komunistami a faszystami ${ }^{11}$ :

1. Stosunek do teraźniejszości. Amerykańscy badacze wskazują, że faszyści i komuniści są niezwykle krytyczni wobec idei i systemów politycznych powstałych w XIX wieku, czyli wobec liberalnej demokracji. Jednak łączy je jedynie krytyka. Wszystkie ruchy totalitarne negują dominację idei XIX stulecia. Faszyzm włoski czyni to z pozycji wspomnień o antycznym Cesarstwie Rzymskim, które chce odbudować w basenie Morza Śródziemnego, a nazizm z pozycji mitologicznej kultury starogermańskiej opartej o czystość rasy. W tym samym czasie liberalnej teraźniejszości komuniści przeciwstawiają mit końca historii, czyli futurystyczną wizję świata postkapitalistycznego. Oto zaprzeczające sobie zmitologizowane utopie retrogradyczne i futurystyczne.

2. Zakres geograficzny mitu. Kolejna różnica to zakres przestrzenny utopii. Komuniści są internacjonalistami i głoszą zniesienie państw, narodów,

11 Ibidem, s. 89-95 (retrogradyzm vs. futuryzm utopii); 133-134 (oznaczenie wrogów); 219244, 256-258 (kwestie własnościowe i ekonomiczne); 279-302 (religia i kościoły). 
tradycyjnych kultur, aby powołać futurystyczne państwo światowe proletariatu. Faszyzm zaś to idea partykularna, dlatego imperia niemieckie i włoskie mają powstać przez podbój sąsiadów, ewentualnie ludów kolorowych. Ich terytorialnym ograniczeniem jest liczebność projektowanego narodu/rasy rządzącej. Niemcy chcą opanować Europę po Ural, a Włosi wybrzeża Morza Śródziemnego.

3. Oznaczenie wrogów. Wskazanie wroga służy politykom totalitarnym do przeprowadzenia skutecznej mobilizacji politycznej społeczeństwa, przygotowania go do wyrzeczeń i poniesienia strat ludzkich. Walka z wrogami jest także sposobem auto-legitymizacji własnej władzy. Faszyści i naziści wskazują na wrogów o charakterze narodowym, rasowym lub etnicznym, czego klasycznym przykładem jest stosunek hitlerowców do Żydów. Dla komunistów wrogiem są kapitaliści, a archetypem tych ostatnich w okresie zimnej wojny stali się Amerykanie.

4. Własność. Domagając się drobiazgowej kontroli życia społecznego wszystkie totalitaryzmy ex definitione są przeciwne zasadzie wolnego rynku, czyli swobodzie obrotu i korzystania z własności, zawierania umów, pojęcia ceny jako miejsca spotkania się popytu z podażą itp. Wszystkie proponują w to miejsce gospodarkę centralnie planowaną (pod różnymi nazwami). Totalitaryści nie są jednakże zgodni w swoim stosunku do własności prywatnej. Komuniści głoszą jej zniesienie i upaństwowienie, a faszyści dążą do zachowania własności w rękach prywatnych, której mogą być pozbawieni jedynie wrogowie (na przykład Żydzi). Komuniści odwołują się do mas ubogich robotników i bezrolnych chłopów, którzy nie posiadają własności. Postawa utrzymania instytucji własności prywatnej faszystów wynika z ich programowego antykomunizmu i poparcia udzielonego im przez klasę średnią.

5. Stosunek do religii i kościołów. Skoro każdy totalitaryzm oparty jest na ideologii będącej quasi-religią, to z natury musi występować przeciwko chrześcijaństwu i tradycyjnym kościołom. Pluralizm ideologiczno-konfesyjny oznaczałby brak absolutnej pewności co do prawdziwości jednej jedynej ideologii i przetrwanie „wysp separatyzmu” 12 . Dlatego każde państwo totalitarne dąży do sekularyzacji i laicyzacji poddanego sobie społeczeństwa. Istnienie zorganizowanych wspólnot religijnych podważa podstawową zasadę etatystycznej kontroli wszystkich i wszystkiego. Komuniści prowadzą z chrześcijaństwem brutalną i otwartą walkę znaczoną prześladowaniami duchownych, wiernych i fizycznym niszczeniem świątyń. Faszyści włoscy i niemieccy zdecydowali się na zawarcie z Kościołem katolickim konkordatów (1929, 1934), ponieważ chcieli pozyskać katolików dla reżimu, przedstawiając się jako zapora przed ateistycznym komunizmem. Mussolini i Hitler liczyli jednak, że przyśpieszą — rozpoczęte przez liberalizm — procesy laicyzacyjne, a ostatecznie ich ideologie trwale wyprą chrześcijaństwo. Nigdy jednak nie prezentowali publicznie swoich antyreligijnych poglądów.

12 Ibidem, s. 302. 
W sumie różnice ideologiczne między poszczególnymi ideologiami totalitarnymi można sprowadzić do jednej zasady: podmiotu polityki. Dla komunistów polityczność ogniskuje się wokół klasy robotniczej, a dzieje postrzegają jako walkę klas; dla nazistów punktem odniesienia jest rasa nordycka, a historia to zapis walki ras; dla faszystów włoskich w centrum stoi naród włoski, a dzieje stanowią zapis jego walki o niepodległość, zjednoczenie państwa i zdobycie imperium. Ta dość banalna konstatacja — w sumie jest to różnica najbardziej oczywista, podstawowa, z której wynikają wyliczone powyżej różnice ideologiczne - w książce Dyktatura totalitarna i autokracja wyrażona jest wprost tylko w jednym miejscu, jakby przypadkiem, pod koniec pracy ${ }^{13}$.

\subsection{Dyktatura nietotalitarna}

W okresie II wojny światowej, w wyniku sojuszu demokracji zachodnich ze Związkiem Radzieckim, utarło się przekonanie, że główną osią sporu polityczno-ideowego jest walka państw faszystowskich z aliantami antyfaszystowskimi. Określenie koalicji jako anty- nie wymagało znalezienia wspólnego mianownika ideowego w wymiarze pozytywnym. Stany Zjednoczone, Wielka Brytania i ZSRR wspólnie walczyły przeciwko faszystowskim państwom Osi. Dlatego i w okresie późniejszym w literaturze, szczególnie pisanej z pozycji marksistowskich, sympatyzującą z Osią Hiszpanię Francisco Franco postrzegano jako faszystowską ${ }^{14}$. Tymczasem będącą od początku po stronie Aliantów, a jakże podobną ideowo do Hiszpanii, Portugalię Antónia Oliveiry Salazara nie klasyfikowano jako państwa faszystowskiego (wyjątek stanowili tutaj portugalscy marksiści) ${ }^{15}$.

Kiedy jednak Franco wszedł w antykomunistyczny sojusz wojskowy z USA (1947-1953), stając się strategicznym sojusznikiem Waszyngtonu w Europie ${ }^{16}$, amerykańscy politolodzy musieli oddzielić Hiszpanię od państw faszystowskich, mimo że nie doszło tutaj do żadnej demokratyzacji ustroju. Zastąpienie kategorii historycznej faszyzmu (stosunek do państw Osi) przez ideologiczną (totalitaryzm) rozwiązywało wszystkie problemy. Friedrich i Brzeziński dowodzą, że Franco zbudował państwo autorytarne, ale nie totalitarne. Przypadek Hiszpanii to problem wzbudzający $\mathrm{w}$ literaturze odwieczne polemiki ${ }^{17}$, ponieważ część

13 Ibidem, s. 359.

14 M. Maciejewski, Hiszpański faszyzm i frankizm w polskiej literaturze politycznej i naukowej (1936-1997), „Studia nad Faszyzmem i Zbrodniami Hitlerowskimi” 21, 1998, s. 267-300.

15 A. Costa Pinto, The Salazar 'New State' and European Fascism, San Domenico 1991, s. $2-5,49-52$.

16 L.L.D. Gómez-Escalonilla, El 'amigo americano'? España y Estados Unidos durante el franquismo, „Studia Historica” 2003, nr 21, s. 237-243; A. Ferrary Ojeda, Los Estados Unidos y el regimen de Franco, 1945-1973, „Memoria y Civilisación” 2018, nr 21, s. 283-311.

$17 \mathrm{~W}$ literaturze przedmiotu spór ten ma bogatą historię, zob. na przykład E. Moradiellos García, Franco y el fascismo, „Temas para el Debate” 2009, nr 172, s. 38-41; P. Preston, D. Gascón, 
badaczy, szczególnie lewicowych z młodzieńczą kartą anty fas zy stow ską, neguje rozdzielenie dyktatur faszystowskich od konserwatywnych.

Carl Friedrich i Zbigniew Brzeziński konsekwentnie podkreślają różnice między dyktaturami totalitarnymi a tradycyjnymi. Klasyczna dyktatura zwykle sprawowana jest przez wysokiego stopniem wojskowego i powstaje drogą zamachu stanu. Dyktatura tradycyjna monopolizuje w rękach dyktatora decyzje polityczne i wymaga od obywateli jedynie zewnętrznego posłuszeństwa. Równocześnie sama pozostaje zewnętrzna w stosunku do życia gospodarczego, rodzinnego i kulturowego, nie mając ambicji przeniknięcia całego życia społecznego. Omnipotencja systemów totalitarnych wynika z ich chęci przeprowadzenia totalnej rewolucji politycznej, ekonomicznej, społecznej i kulturowej. Władza musi nabierać tutaj coraz większych kompetencji, gdyż projekt ten spotyka się z rosnącą niechęcią, oporem biernym, a czasami nawet i czynnym (wojna domowa w Rosji, powstania chłopskie). Nasi autorzy uważają, że Marks, a może nawet jeszcze i Lenin, nie projektowali państwa totalitarnego. Systemy te powstają stopniowo, walcząc z niechęcią społeczną wobec holistycznej zmiany świata. Chęć wdrożenia projektu rewolucyjnego przeobrażenia społeczeństwa różni totalitaryzmy od tradycyjnych dyktatur, wymuszając na tych pierwszych charakter omnipotentny.

Autorzy Dyktatury totalitarnej i autokracji stają wyraźnie w obronie prawicowych i antykomunistycznych dyktatur. Dlatego podkreślają, że w szczególnych okolicznościach politycznych klasyczna dyktatura może stanowić ostatnią redutę obrony tradycyjnego lub mieszczańskiego społeczeństwa przed prącym do władzy ruchem totalitarnym. Jako przykład szczególnie chętnie podają Hiszpanię Franco, gdzie konserwatywny dyktator najpierw zbrojnie zagrodził drogę do władzy komunistom, a w okresie powojennym zręcznie odsunął od władzy faszyzujących falangistów i oparł swoje prawicowe rządy na prawie, choć arbitralnie narzuconym ${ }^{18}$. Podobnie wyglądają prozachodnie dyktatury w Pakistanie i w Turcji, gdzie „brak jest totalnej ideologii” i chęci dokonania „totalnej destrukcji, a potem rekonstrukcji społeczeństwa" wedle ideologicznej receptury ${ }^{19}$. Identycznie ocenione zostają historycznie pierwsze dyktatury Olivera Cromwella w Anglii, Napoleona, a nawet Maximiliena Robespierre'a we Francji, które - przy całej emancypacyjnej frazeologii - miały charakter konserwatywny społecznie i za jeden z celów stawiały sobie obronę zastanego własnościowego status quo ${ }^{20}$. Innymi słowy, dyktatury tradycyjne są nastawione antykomunistycznie.

'Franco no era fascista. Era algo peor', „Letras Libres” 2015, nr 170, s. 22-27 (teza o totalitaryzmie); J. Linz, Un régimen autoritario: España, Helsinki 1964; J. Tusell, La dictadura de Franco, Madrid 1996 (teza o autorytaryzmie).

18 C.J. Friedrich, Z. Brzeziński, op. cit., s. 8-9.

19 Ibidem, s. 9, 19-20.

20 Ibidem, s. 161-162. 


\section{Krytyka koncepcji totalitaryzmu}

Opis totalitaryzmu, dokonany przez Carla Friedricha i Zbigniewa Brzezińskiego, powstał w czasie, gdy badania nad tym zjawiskiem nie były jeszcze zaawansowane, a samo pojęcie wzbudzało duże emocje. Do 1945 roku termin ten odnoszono głównie do Italii Benito Mussoliniego, która ustami swojego Duce sama określała się jako „państwo totalitarne” (stato totalitario). Jakkolwiek termin ten ukuli przeciwnicy faszyzmu, to Mussolini przejął go, nadając mu pozytywny wydźwięk silnego państwa ${ }^{21}$. Analogicznie, ponieważ III Rzesza w okresie II wojny światowej znajdowała się w sojuszu z Włochami, a ideologia hitleryzmu wykazywała znaczące podobieństwa do faszyzmu, to pod pojęciem totalitarnych rozumiano przede wszystkim państwa Osi. Hitler i hitlerowcy, głosząc prymat Volku nad ideą państwa, terminu tego nie lubili. Poza tym jego włoskie pochodzenie sugerowałoby, że nazizm pochodzi z importu. W Niemczech określenie totalizm pojawia się pośród współpracujących z III Rzeszą konserwatywnych prawicowych heglistów (Carl Schmitt i Ernst Forsthoff ${ }^{22}$ ), ale nie zostaje zaakceptowane, gdyż jego treść bliższa była klasycznemu autorytaryzmowi. W tym czasie określanie tak ZSRR było kłopotliwe z racji sojuszu przeciwko III Rzeszy, gdy na Zachodzie samą wojnę przedstawiano jako walkę idei wolności ze zniewoleniem.

Krytycy powojennej koncepcji totalitaryzmu wskazywali, że ma ona źródła polityczne, czyli pozanaukowe. Gdy w okresie zimnej wojny byłe państwa Osi (RFN, Włochy, Japonia) stały się sojusznikami Stanów Zjednoczonych i przyjęły ustrój liberalno-demokratyczny, to nowa sytuacja czyniła z totalitaryzmu faszystowskiego zjawisko historyczne. Jednakże określenie Związku Radzieckiego jako państwa totalitarnego automatycznie czyniło go systemowo podobnym do państw faszystowskich, które w wyniku doświadczeń wojennych kojarzono teraz głównie z Holocaustem, ludobójstwem i zbrodniami wojennymi. To zaś czyniło państwa Stalina i jego satelitów nie tylko wrogimi, ale też bytami politycznymi odczłowieczonymi, zbrodniczymi i moralnie niższymi, uzasadniając przed światem nauki i opinią publiczną antykomunistyczną politykę Waszyngtonu. Ten zabieg naukowy pozwalał postawić ZSRR - niedawnego sojusznika zachodnich demokracji — na jednym poziomie moralno-politycznym z III Rzeszą. Pamiętajmy, że słowo „totalitaryzm” wiąże się z samymi negatywnymi emocjami, czyniąc zbędnymi dogłębne analizy i wyrafinowaną intelektualnie argumentację ${ }^{23}$. Podobnie polityczny wymiar miało naukowe rozróżnienie Friedricha i Brzezińskiego

21 J. Petersen, La nascita del concetto di 'Stato totalitario' in Italia, ,Annali dell'Istituto Storico Italo-Germanico di Trento" 1, 1975, s. 143-168; S. Forti, El totalitarismo. Trayectoria de una idea límite, Barcelona 2008, s. 35-84.

22 E. Fortshoff, Der totale Staat, Hamburg 1933; C. Schmitt, Positionen und Begriffe im Kampf mit Weimar-Genf-Versailles 1923-1939, Berlin 1994 [1940], s. 166-178 (tekst z 1931 roku) i 211-216 (tekst z 1933 roku).

23 R. Skarzyński, Od liberalizmu do totalitaryzmu, Warszawa 2002, t. 2, s. 41-42. 
systemów totalitarnych od prawicowych autorytaryzmów, gdyż te drugie były głęboko antykomunistyczne (na przykład Hiszpania Franco i Portugalia Salazara), a w swojej polityce powojennej orientowały się na sojusz z Waszyngtonem.

W literaturze krytycznej zwracano uwagę, że w dokonaniu powyższych naukowo-ideowych wolt praca Dyktatura totalitarna i autokracja stanowiła dzieło pionierskie ${ }^{24}$, acz Stany Zjednoczone znakomicie się nadawały do tej wolty pojęciowej. Amerykański czytelnik był z totalitaryzmem już oswojony, gdyż stykał się z tym terminem na łamach prasy od przełomu lat dwudziestych i trzydziestych do 1941 roku („New York Times”, „Washington Post”, „Time”, trockistowski „Partisan Review”). Ta sama prasa od 1945-1946 roku konsekwentnie zaczyna określać mianem totalitarnych państwa komunistyczne ${ }^{25}$.

Wskazane powyżej manewry naukowo-ideowe Friedricha i Brzezińskiego, wprowadzające do obiegu naukowego pojęcie totalitaryzmu i walki z nim jako punktu centralnego powojennej politologii, były krytykowane z różnych kierunków.

1. Krytyka zachodnich badaczy lewicowych. Naukowcy ci wyraźnie sympatyzowali z ZSRR, nawet jeśli wielu z nich, a stopniowo nawet większość, widziała, że między emancypacyjną utopią Karola Marksa a państwem Lenina i Stalina zachodzi antyteza. Mimo wszystkich formułowanych zastrzeżeń wobec tak zwanego realnego socjalizmu postrzegali ZSRR jako kraj postępowy, antyklerykalny, antykapitalistyczny, co - mimo nadużyć, dyktatury monopartii i terroru - powodowało ich niezdolność do obiektywnego spojrzenia na fakty. Postawienie na jednym poziomie komunizmu i nazizmu stanowiło dla nich

24 B.R. Barber, H.J. Spiro, Counter-Ideological Uses of 'Totalitarianism', „Politics and Society” 1, 1971, nr 3, s. 3-21; J.-M. Fontaine, À quoi sert le totalitarisme?, „L'Homme et la Société” 1984, nr 71-72, s. 7-21; I. Kershaw, Qu'est-ce que le nazisme? Problèmes et perspectives d'interpretation, Paris 1997, s. 54-55; E. Traverso, Introduction. Le totalitarisme. Jalons pour l'histoire, [w:] Le totalitarisme, Paris 2001, s. 51-60. Gwoli ścisłości, w naszej ocenie pierwszeństwo w tej redefinicji pojęciowej należy się jednak H. Arendt (Korzenie totalitaryzmu, Warszawa 1993 [1953], t. 1-2). W literaturze często zwracano uwagę, że dla badaczki tej pojęcie totalitaryzmu odnosiło się tylko do III Rzeszy i ZSRR, ponieważ pominęła w swoich analizach Włochy Mussoliniego i prawicowe dyktatury (M. Canovan, The Leader of the Masses: Hannah Arendt on Totalitarianism and Dictatorship, [w:] Dictatorship in History and Theory. Bonapartism, Cesarism, and Totalitarianism, red. P. Baehr, M. Richter, Cambridge 2004, s. 241-248; E. Gentile, La silence de Hannah Arendt. L'interprétation du fascisme dans 'Les origines du totalitarisme', „Revue d'Histoire Moderne et Contemporaine” 55, 2008, nr 3, s. 11-34). W pomniejszych tekstach podobne tezy przedstawiali wcześniej także inni autorzy: G. Salvemini, Pour la liberté de l'esprit [1935], [w:] Le totalitarisme, s. 245-249; L. Sturzo, Morale et politique. Orientations et expérience, Paris 1938, s. 19-33; F. Borkenau, The totalitarian enemy, London 1940, s. 11-19; R. Hilferding, Capitalisme d'État ou économie d'État totalitaire [1940], [w:] Le totalitarisme, s. 374 383; H. Kohn, Revolution and Dictatorships. Essays in contemporary history, Cambridge 1941, s. $179-199$.

25 J.F. Fuentes, Totalitarismo: origen y evolución de un concepto clave, „Revista de Estudios Politícos" 2006, nr 134, s. 200-201, 209-210 (tamże dokładne dane statystyczne). Badacz ten zauważa, że dziś w Stanach Zjednoczonych publicyści chętnie piszą o „totalitaryzmie islamskim” i ,islamofaszyzmie", co stanowi kolejną mutację przeciwstawienia wolności (USA) zniewalającemu ludzi totalitaryzmowi wrogów USA (s. 217-218). 
herezję ideologiczną i manipulację ze strony burżuazyjnych naukowców ${ }^{26}$. Słowem, lewicowi badacze, a także i politycy ${ }^{27}$, byli niezdolni do postawienia na jednym poziomie Związku Radzieckiego i III Rzeszy, a następnie do określenia obydwu jako podobnych $\mathrm{w}$ istocie państw totalitarnych, podobnie rządzonych, a różniących się tylko głoszoną ideologią, z czego wynikało wskazanie innych grup ludzkich jako wrogów i poddanych eksterminacji. We Francji socjalistyczny minister edukacji jeszcze w 1985 roku odradzał nauczycielom używania terminu „totalitaryzm” w stosunku do ZSRR ${ }^{28}$. Stąd tak wielkie poruszenie we Francji wywoływało postawienie na jednym poziomie — i określenie wspólnym mianem totalitaryzmu — faszyzmu włoskiego, nazizmu w Niemczech i stalinizmu w ZSRR. Każdy tekst przedstawiający taką tezę ${ }^{29}$ wzbudzał tutaj wielkie kontrowersje. Naukowcy lewicowi nie potrafili także uznać państw prawicowo-autorytarnych za niefaszystowskie. Bezkrytycznie wzorując się na pracach Marksa na temat bonapartyzmu we Francji ${ }^{30}$, uważali wszelkie niedemokratyczne systemy broniące własności prywatnej za jednaką czy bardzo podobną terrorystyczną formę panowania burżuazji nad proletariatem, dla której faszyzm stanowić miał niedościgniony archetyp ${ }^{31}$. Co ciekawe, w RFN, gdzie łatwo było zauważyć

${ }^{26}$ C. Lefort, La logique totalitaire [1980], [w:] Le totalitarisme, s. 712-714; E. Traverso, op. cit., s. 45-48; S. Courtois, Ernst Nolte: penser le fascisme et le totalitarisme, [w:] Fascisme et totalitarisme, red. E. Nolte, Paris 2008, s. XVII-XXV.

27 Zob. na przykład artykuł przewodniczącego FPK R. Hue, La marche du siècle antistalinien jusqu'au bout, „L'Humanité”, 5.11.1997.

28 S. Courtois, Ernst Nolte, s. XXII.

${ }^{29}$ Chyba największy rozgłos wywołali: F. Furet, Przeszłość pewnego złudzenia. Esej o idei komunistycznej w XX w., Warszawa 1996 [1995], s. 203-266; K. Pomian, Totalitarisme, „Vingtième Siècle" 1995, nr 47, s. 4-23.

${ }^{30}$ K. Marks, Osiemnasty brumaire'a Ludwika Bonaparte [1852], [w:] K. Marks, F. Engels, Dzieła wybrane, Warszawa 1981, t. 1, s. 620-714. Interesującą analizę mieszczańskiej dyktatury wyłaniającej się z tego dzieła przedstawiają na przykład J. Schleifstein, Marxismus und Staat. Zur Entwicklung der Staatsauffassung bei dem marxistischen Klassikern, Frankfurt am Main 1982, s. 31-41; T. Carver, Marx's 'Eighteenth Brumaire of Louis Bonaparte': Democracy, Dictatorship, and the Politics of Class Struggle, [w:] Dictatorship in History..., s. 103-128. O wpływie tej koncepcji na marksistowską interpretację faszyzmu zob. R. Saage, Faschismus. Konzeptionen und historische Kontexte, Wiesbaden 2007, s. 55-63.

31 Zob. przede wszystkim klasyczne teksty: A. Bordiga, Stato, capitalisti e ceti medi [1922], [w:] Interpretazioni del fascismo, red. C. Casucci, Bologna 1982, s. 405-410; C. Zetkin, Der Kampf gegen den Faschismus [1923], [w:] Theorie über den Faschismus, red. E. Nolte, Köln 1967, s. 88111; P. Togliatti, Grossa e piccola borghesia [1928], [w:] Interpretazioni del fascismo, s. 411-428; P. Tresso, Fascismo repressione capitalistica [1930], [w:] Interpretazioni del fascismo, s. 429-434; H. Marcuse, Walka z liberalizmem w totalitarnej koncepcji państwa [1934], [w:] Szkoła Frankfurcka, red. J. Łoziński, Warszawa 1985, t. 2, s. 381-408; O. Bauer, Der Faschismus [1936], [w:] Faschismus und Kapitalismus, red. W. Abendroth, Wien 1967, s. 143-168; D. Guérin, Fascisme et grand capital, Paris 1999 [1938]; N. Poulantzas, Fascisme et dictature, b.m.w. 1974 [1970]. 
podobieństwa między III Rzeszą a komunizmem w NRD, teza o totalitarnej wspólnej tożsamości nazizmu i komunizmu nie budziła takich kontrowersji ${ }^{32}$.

2. Urzędowa krytyka w bloku wschodnim. Interpretacja marksistowska miała tutaj charakter quasi-kanoniczny w badaniach historycznych i politologicznych, dlatego Richard Saage określa ją mianem nie tyle marksistowskiej, co „sowiecko-marksistowskiej"33. Na przykład w Polsce zaczęto ją podawać w wątpliwość dopiero w drugiej połowie lat siedemdziesiątych XX wieku, gdy Jerzy Holzer oddzielił dyktatury faszystowskie od prawicowo-autorytarnych ${ }^{34}$. Oczywiście aż do 1989 roku nie była możliwa jakakolwiek dyskusja o podobieństwach między III Rzeszą a Związkiem Radzieckim w oficjalnym obiegu naukowym, czyli zakazane było używanie samego pojęcia totalitaryzmu w rozumieniu zrównania państw Hitlera i Stalina, gdyż nie wolno było analizować istoty systemu radzieckiego. Nic też dziwnego, że w języku polskim nie mogły ukazać się klasyczne rozprawy o totalitaryzmie Hannah Arendt, Carla Friedricha i Zbigniewa Brzezińskiego, a także innych autorów.

3. Krytyka badaczy antynacjonalistycznych. Część współczesnych badaczy nadal odrzuca pojęcie totalitaryzmu, ponieważ faszyzm, a szczególnie nazizm, wydawał im się złem wcielonym. Dla części badaczy faszystowski nacjonalizm i nazistowski rasizm były czymś nie do zaakceptowania, ponieważ po zachodnich doświadczeniach z nazizmem, urzędowym antysemityzmem i Holocaustem, uznawano te doktryny za zbrodnicze, a głoszące je systemy za najgorsze z możliwych. Wskazywano, że celem polityki hitlerowskiej była fizyczna eksterminacja milionów ludzi z powodu rasowych przesądów. Oczywiście, dostrzegano także miliony ofiar stalinizmu, maoizmu, polpotyzmu itp., ale patrzono na nie inaczej. W nazizmie dostrzegano wielką rewoltę przeciwko dziedzictwu renesansu, oświecenia i humanizmu w imię trybalizmu i reakcyjnego barbarzyństwa. Dlatego starano się usprawiedliwiać, pomniejszać, okazywać zrozumienie dla systemu radzieckiego, który przynajmniej miał szczytne cele: humanistyczne, kosmopolityczne, chciał wyemancypować i wyzwolić ludzkość w przyszłości itp. Jak to ujął Jean-Marie Colombani, na zbrodnie komunistyczne trzeba patrzeć przez palce, ponieważ dopuścili się ich ludzie „wierzący w wielkie ideały"35. Przy okazji pojawiła się również dyskusja na temat liczby ofiar komunistycznego

32 Zob. na przykład K.D. Bracher, Totalitarismus und Faschismus, Münich 1980, s. 10-17, 5354, 69-70; M. Schöngarth, Die Totalitarismusdiskussion in der neuen Bundesrepublik 1990 bis 1995, Köln 1996; D. Schmiechen-Ackermann, Diktaturen im Vergleich, Darmstadt 2002; E. BojenkoIzdebska, Dwa totalitaryzmy w Niemczech - dyskusja wokót teorii porównawczej na przykładzie oceny systemu NRD, [w:] Totalitaryzmy XX wieku. Idee, instytucje, interpretacje, red. W. Kozub-Ciembroniewicz et al., Kraków 2010, s. 267-269.

33 R. Saage, op. cit., s. 24-48.

34 J. Holzer, System faszystowski a autorytarny. Uwagi polemiczne, „Studia nad Faszyzmem i Zbrodniami Hitlerowskimi” 3, 1977, s. 271-278.

35 J.-M. Colombani, Le communisme et nous, „Le Monde”, 5.12.1997. Problem ten thumaczy - jako neojakobińską wiarę w uprawomocnienie ideału do używania metod terrorystycznych 
terroru, którą w Czarnej księdze komunizmu (1997) oceniono na około 100 milionów na całym świecie ${ }^{36}$, podczas gdy lewicowi historycy próbują ją redukować z ocen przybliżonych, do liczb weryfikowalnych źródłowo, co krytyk tej strategii, Laurent Joffrin, skomentował następującym pytaniem: ,jeśli zamordowano nie 80, lecz 50-60 milionów ludzi, to czy komunizm staje się tym samym bardziej akceptowalny?"37.

4, Krytyka naukowców żydowskiego pochodzenia. W literaturze spotykamy także badaczy, dla których termin „totalitaryzm” - ujmujący łącznie nazizm i komunizm - oznacza postawienie na jednym poziomie III Rzeszy, ZSRR, Włoch i Chin maoistycznych, w czym widzą jakby metafizyczny zamach stanu na wyjątkowość i niepowtarzalność Holocaustu. Pośród tego kierunku krytyki, co zrozumiałe, przeważają naukowcy żydowskiego pochodzenia, uważający, że określenie „totalitaryzm” stawia na jednym poziomie ofiary pochodzące z narodu wybranego, a pomordowane w czasie Holocaustu, z przypadkowymi ofiarami gułagów czy rewolucji kulturalnej zabitymi z powodu przynależności klasowej lub zupełnie z przypadku ${ }^{38}$.

W naszej ocenie wskazane tutaj zastrzeżenia odnośnie do tez autorów rozprawy Dyktatura totalitarna i autokracja o istnieniu typu państwa totalitarnego nie wytrzymują krytyki, nawet jeśli postawione przez Friedricha i Brzezińskiego teorie miały w okresie zimnej wojny polityczną atrakcyjność dla polityki amerykańskiej i z tego względu były promowane. Wskażmy trzy argumenty.

1. Niezrozumienie pojęcia typu idealnego. Badacze negujący istnienie totalitaryzmu jako takiego uwielbiają wchodzić w rozmaite szczegóły uzasadniające niemożność przyjęcia wspólnej klasyfikacji nazizmu, faszyzmu i komunizmu. Wskazywano na różnice ideologiczne, przyjęcie odmiennych podmiotów (rasa, naród, klasa społeczna), inaczej wyznaczonych wrogów, różnice w strukturze własności systemów ekonomicznych, oparcie władzy na innych grupach społecznych itp. ${ }^{39}$ Różnic tych nikt nie neguje, także Friedrich i Brzeziński byli ich świadomi i dlatego poświęciliśmy im jeden z wcześniejszych fragmentów tego tekstu. Jak pisze Richard Saage, wskazanie przez tych dwóch badaczy „po-

- Ch. Prochasson, Le terrorisme de la vertu, [w:] Les Gauches françaises, 1762-2012. Figures et paroles, red. J. Julliard, Paris 2014, s. 326-327.

36 S. Courtois, Zbrodnie komunizmu, [w:] Czarna księga komunizmu. Zbrodnie, terror, prześladowania, red. S. Courtois et al., Warszawa 1999 [1997], s. 25-26.

${ }^{37}$ L. Joffrin, Ceux qui cherchent à relativiser les crimes du communisme, chargeant Stalin seul, ne sont fidèles qu'à leurs erreuers. Sauver Lénine?, „Libération”, 17.11.1997.

38 S. Friedländer, Le nazisme: fascisme ou totalitarisme [1985], [w:] Le totalitarisme, s. 801811; I. Kershaw, Retour sur le totalitarisme. Le nazisme et le stalinisme dans une perspective comparative [1994], [w:] Le totalitarisme, s. 862-865; E. Traverso, op. cit., s. 73-74, 100-103.

39 Na przykład J. Kocka, Geschichte und Aufklärung, Göttingen 1989, s. 114-119; I. Kershaw, Retour sur le..., s. 853-854; J.L. Talmon, Le origini della democrazia totalitaria, Bologna 2000 [1952], s. 14-17. Znakomitą krytykę (a przy okazji opis) tego stanowiska przedstawia J. Linz, Totalitarian and authoritarian Regimes, London 2000, s. 117-136. 
dobieństwa nie oznacza ich identyczności” ${ }^{40}$. Badacze posługujący się terminem „totalitaryzm” nie twierdzą przecież, że III Rzesza, Italia Mussoliniego, ZSRR Stalina i Chiny Mao są identyczne, a jedynie, iż są podobne, iż państwa te rządzone są na podstawie bliźniaczej logiki i zbliżonych zasad. Totalitaryzm to pojęcie w rozumieniu weberowskiego typu idealnego, czyli wzorzec wypracowany na podstawie analizy kilku przypadków, który w 100\% może nie pasować do żadnego z nich ${ }^{41}$. Stąd tendencja, aby terminu „totalitaryzm” nie opisywać nadmiernie szczegółowo, a jedynie wskazać — tak jak to uczynili Brzeziński i Friedrich kilka cech charakterystycznych dla wszystkich państw spełniających definicyjne minima totalitarne.

2. Rozpad mitu postępowego ZSRR. Lewicowi politycy, dziennikarze i naukowcy z Zachodu przez kilka dziesięcioleci nie przyjmowali do wiadomości, że w Związku Radzieckim panuje terror, a ludność żyje w nędzy. Jakkolwiek dostrzegano w ZSRR rozmaite wypaczenia lewicowych ideałów, to chyba tylko śmiertelnie skłóceni ze stalinistami trockiści przedstawiali rzeczywistość komunistyczną taką, jaka ona była $\mathrm{w}$ istocie, czyli jako terrorystyczne rządy. Rozpad ZSRR i upadek bloku wschodniego spowodowały masowy napływ imigrantów ze Wschodu, chętnie dzielących się doświadczeniami z życia w tak zwanym realnym socjalizmie. Po otwarciu archiwów w krajach postkomunistycznych nie dało się nie dostrzec skali terroru, cenzury, inwigilacji i prześladowań. O ile książki Sołżenicyna na temat systemu gułagów można było ignorować jako stronnicze, to archiwów samych państw komunistycznych już nie. Zaowocowało to kryzysem zachodnich partii komunistycznych i kompromitacją tez lewicujących badaczy, wybielających ZSRR i umniejszających zbrodnie komunistyczne. Szczególne wrażenie zrobiła na Zachodzie praca zbiorowa Czarna księga komunizmu ${ }^{42}$, sprzedana w ponad milionie egzemplarzy na całym świecie, w 27 językach, wzbudzając liczne i gwałtowne polemiki ze strony komunizującej lewicy francuskiej i włoskiej ${ }^{43}$. W świecie niemieckojęzycznym podobne wrażenie wywołały tezy Ernsta Noltego, twierdzącego, że nazizm był reakcją na komunizm i przy zastosowaniu zbliżonych do komunizmu metod walki politycznej i organizacji państwa, co także oznaczało zdjęcie zeń znamienia wyjątkowości i niepowtarzalności, wpisując ten fenomen w totalitarną logikę XX wieku ${ }^{44}$.

40 R. Saage, op. cit., s. 110.

41 J. Linz, Totalitarian and authoritarian..., s. 131-132.

42 Czarna księga...

43 Polemiki we Francji omawiają P. Rigoulot, I. Yannakakis, Un pavé dans l'histoire: le débat français sur Le Livre noir du communisme, Paris 1998; we Włoszech M. Flores, Le débat italien sur le communisme entre chronique et histoire, „Matériaux por l'Histoire de notre Temps” 2002, nr 68, s. 46-50. W polemice tej kluczowe są dwie prace zbiorowe krytyków Czarnej księgi komunizmu: Sul libro nero del comunismo, Roma 1998; Les siècle des communismes, Paris 2000 (wydanie poszerzone do prawie 800 stron w 2004).

44 ,Historikerstreit‘. Die Dokumentation der Kontroverse um die Einzigartigkeit der nationalsozialistischen Judenvernichtung, red. E. Piper, München 1987. 
3. Wyjątkowość Holocaustu. W literaturze tezie o ekscepcjonalności Zagłady przeciwstawia się wielu badaczy, dowodzących, że każdy zamordowany człowiek ma taką samą wartość, bez względu na jego narodowość, rasę, pochodzenie klasowe i religię. Na przykład francuski naukowiec (bułgarskiego pochodzenia) Tzvetan Todorov pisze, że u źródła poglądu o wyjątkowości Holocaustu i niemożności porównania $\mathrm{z}$ tego powodu zbrodni hitlerowskich i stalinowskich kryje się irracjonalny pogląd, że „życie ukraińskiego starca ma mniejszą wartość niż żydowskiego starca, gdyż przodkowie tego drugiego wynaleźli monoteizm" 45 . W naszym przekonaniu chodzi o coś znacznie ważniejszego niż historyczne źródła monoteizmu: w tym proteście przeciwko pojęciu totalitaryzmu wyraźnie uwidacznia się - mocno zsekularyzowane, ale dość czytelne - świadome czy podświadome subiektywne przekonanie badaczy żydowskiego pochodzenia o wyjątkowości własnego narodu i jego wybraństwie przez Boga, co uniemożliwia im porównywanie sześciu milionów ofiar Holocaustu z milionami Ukraińców wymordowanych w czasie kolektywizacji i dziesiątkami milionów ofiar systemu gułagów. Oczywiście każdy ma prawo uważać się za członka narodu wyjątkowego czy wybranego przez Boga, ale trudno taki pogląd uznawać za naukowy i mogący prawowicie rzutować na klasyfikację typów państw. Stąd słuszna wydaje się nam postawa tych badaczy, którzy weszli z tezami o rzekomej nieporównywalności zbrodni nazistowskich $\mathrm{z}$ innymi w polemikę nie w naukowych tekstach, ale w polemikach i wywiadach prasowych, pozwalających wyraziściej przedstawić swoje poglądy ${ }^{46}$.

\section{Pogląd autorski}

$\mathrm{Na}$ zakończenie chcemy przedstawić nasze stanowisko wobec omawianych, a wywołujących kontrowersje kwestii, czyli sprawy możności lub niemożności wyodrębnienia typu idealnego państwa totalitarnego w ramach którego mieszczą się zarówno wszelkie odmiany faszyzmu, jak i komunizmu; rozróżnienia typu państwa totalitarnego od autorytarnego; stopniowalności krytyki terroru i ludobójstwa ze względu na przyświecające mu idee.

\subsection{Kwestia fundamentalna 1: typ idealny totalitaryzmu}

W pełni zgadzamy się z tezą Carla Friedricha i Zbigniewa Brzezińskiego która często dziś jest przedstawiana przez badaczy interesującego nas zjawiska ${ }^{47}$

45 T. Todorov, Le totalitarisme, encore une fois [1997], [w:] Le totalitarisme, s. 796.

46 S. Courtois, La tragédie communiste, „Le Monde”, 20.12.1997; M. Lefebvre, N. Werth, Le communisme, entre analyse scientifique et vision policière de l'historie, „Le Monde”, 21.09.2000.

${ }^{47} \mathrm{Na}$ przykład w: C.J.H. Hayes, The Novelty of Totalitarianism in the History of Western Civilization, „Proceedings of the American Philosophical Society” 82, 1940, nr 1, s. 91-102; K. Jaspers, La lutte contre le totalitarisme [1954], [w:] Le totalitarisme, s. 460-472; J. Monnerot, Socio- 
— że totalitaryzm jest jednym z możliwych wyrazów społeczeństwa masowego, obok liberalnej demokracji. Nowożytne, a szczególnie dziewiętnastowieczne zjawiska industrializacji, rozwoju miast i boomu demograficznego, połączone z rozpadem tradycyjnych (stanowych, korporacyjnych i regionalnych) struktur społecznych i powszechną laicyzacją społeczną, utratą wiary w życie pośmiertne, czyli poczucie sensu istnienia, wywołały poważny kryzys egzystencjalny. Wielkie miasta stworzyły masy w miejsce organicznych wspólnot. Te wielkie skupiska ludzkie nie miały jednakże łączących je więzi. Członkowie tych mas przestali czuć się częścią wielopokoleniowych rodzin, utracili zakorzenienie regionalne, rozmyły się więzi stanowe. Pojawienie się żyjącego w dramatycznych warunkach proletariatu i odgórne reformy prawne tworzące wolny rynek zniszczyły system wspólnot cechowych i korporacyjnych. W XIX wieku zaczęly przeto kształtować się nowe poczucia identyfikacji, charakterystyczne dla społeczeństwa masowego, dla ludzi, którzy potrzebowali wspólnotowej identyfikacji, którzy w indywidualistycznym liberalizmie czuli się wyalienowani i wykorzenieni. Były to nacjonalizm i marksizm. Pierwszy nauczał, że łączy nas przynależność do jednego narodu, gdy ten drugi, iż łączy nas solidarność klasowa o charakterze internacjonalistycznym, idąca w poprzek podziałów etnicznych. Dlatego, jak już to rozrysowywaliśmy przy innych okazjach, obydwie te idee XIX wieku skazane były na śmiertelny konflikt, skoro w sposób odmienny, wręcz sprzeczny, wskazywały centralny podmiot lojalności i tożsamości w epoce masowej: naród (byt ponadklasowy) albo klasę (byt ponadnarodowy) ${ }^{48}$.

Pojawienie się nowych identyfikacji było jednym z elementów powstawania nowej samoświadomości, charakterystycznej dla społeczeństwa masowego. W żadnym razie nie musiało to prowadzić do narodzin zjawiska totalitaryzmu. Wszak nacjonalizm do przełomu XIX i XX wieku był liberalny i głosił postulaty demokratyczne. Marks najprawdopodobniej także nie miał świadomości dokąd mogą zaprowadzić jego idee i sam postrzegał siebie jako ideologa emancypacji społecznej, kontynuatora tradycji oświecenia i idealizmu niemieckiego. Przekształcenie się marksizmu w leninizm i stalinizm, a nacjonalizmu w faszyzm i narodowy socjalizm, to skutki I wojny światowej. Tak zwany socjalizm wojenny (Kriegssozialismus), czyli etatyzacja gospodarki w celu maksymalizacji produkcji na potrzeby I wojny światowej, pokazał ludom Europy nieprawdopodobne możliwości ekonomiczne państwa w ramach gospodarki planowej, w sytuacji totalnej mobilizacji ${ }^{49}$.

logie de la révolution. Mythologies politiques du XXe siècle, Paris 1969, s. 538-544; F. Furet, Les différents aspects du concept de totalitarisme [1996], [w:] Le totalitarisme, s. 875-876; E. Traverso, op. cit., s. 9-18; R. Skarzyński, op. cit., t. 2, s. 44-57; D. Riley, The civic foundations of fascism in Europe. Italy, Spain, and Romania, 1870-1945, Baltimore 2010, s. 1-22.

48 A. Wielomski, Nacjonalizm francuski 1886-1940. Geneza, przemiany i istota filozofii politycznej, Warszawa 2007, s. 13-130; M. Ziętek-Wielomska, A. Wielomski, Nowoczesność, nacjonalizm, naród europejski. Dylematy samoidentyfikacji Europejczyków, Warszawa 2017, s. 67-82.

49 F. Redlich, German Economic Planning for War and Peace, „The Review of Politics” 6, 1944, nr 3, s. 315-335; F.-W. Henning, Das industrialisierte Deutschland, 1914 bis 1978, Paderborn 
Jak się zdaje, sam przymiotnik totalitarny/totalny pochodzi od określenia I wojny światowej jako wojny totalnej ${ }^{50}$. Z kolei cztery lata spędzone przez dwa pokolenia w okopach wymazały trwale idee humanistyczne ze świadomości społecznej. Generacja, która wyszła z okopów wojennych, nie gardziła przemocą w polityce, uznając ją za normalny środek walki o swoje idee i interesy. Słowem, świat zaakceptował państwo wszechwładne i brutalizację polityki równocześnie ${ }^{51}$.

Doświadczenia te radykalnie przedefiniowały marksizm i nacjonalizm. Humanistyczno-futurystyczna utopia marksizmu, połączona z formułą gospodarki wojennej i akceptacją przemocy politycznej, zaowocowały rewolucją październikową w Rosji, brutalną wojną domową, a ostatecznie narodzinami państwa terrorystycznego w imię walki klas, co oznaczało klęskę demokratycznego socjalizmu głoszącego tak zwany reformizm i rewizjonizm, jak i zwinięcie sztandaru emancypacji. Równocześnie nacjonalizm zaczął mutować się w faszyzm i narodowy socjalizm, chociaż różne są interpretacje tej przemiany. Ernst Nolte głosi, że była to reakcja na zwycięstwo Lenina w Rosji i wyraz przerażenia klasy średniej informacjami o rzeziach burżuazji i ziemiaństwa. W tej sytuacji wystraszona klasa średnia zapragnęła eksterminować bolszewików (i Żydów, uważanych w Niemczech za przywódców i ideologów partii komunistycznych), aby uprzedzić wybuch lub przyniesienie na karabinach radzieckich rewolucji komunistycznej ${ }^{52}$. Inaczej interpretuje problem Zeev Sternhell, uważający, że faszyzm stanowi syntezę wyniesionego z okopów szowinistycznego nacjonalizmu i herezję od socjalizmu, który odrzucił walkę klas na rzecz socjalizmu w ramach wspólnoty narodowej (solidaryzm) $)^{53}$.

Oczywiście, faszyzm i komunizm wykazują znaczące różnice ideologiczne, ponieważ charakteryzują je inne podmioty historyczne, które mają rządzić światem i zbudować imperium. Dla faszystów włoskich są to narody, dla narodowych socjalistów rasa nordycka, dla leninistów proletariat światowy, a dla maoistów klasa chłopska. Z tej podstawowej różnicy podmiotowej wynikają wszystkie podstawowe różnice ideologiczne, a z nich wzajemna nienawiść faszystów i komunistów. Dla faszysty komunista jest wrogiem najgorszym z najgorszych, ponieważ za pomocą ideologii klasowej próbuje rozerwać wspólnotę narodową (faszyzm klasyczny) lub rasową (nazizm) na śmiertelnie skonfliktowane grupy społeczne. Z kolei dla komunisty faszysta także jest wrogiem najgorszym z możliwych, ponieważ odrzuca samo istnienie klas, podczas gdy on sam uważa je za podmiot

1979, s. 32-50; H. Kellenbenz, Deutsche Wirtschaftsgeschichte, München 1981, t. 2, s. 340-353.

50 R. Skarzyński, op. cit., t. 2, s. 62-63; J.F. Fuentes, op. cit., s. 204-205.

51 E. Halévy, L'Ére des tyrannies. Études sur le socialisme et la guerre, Paris 1938, s. 213-215.

52 E. Nolte, Der Faschismus in seiner Epoche. Action française, Italienischer Faschismus, Nationalsozialismus, München 1979, s. 51. Egzemplifikację tej tezy stanowi praca idem, Der europäische Bürgerkrieg 1917-1945. Nationalsozialismus und Bolschewismus, München 2000.

53 Z. Sternhell, The 'Antimaterialism Revision' of Marxism as an Aspect of the Rise of Fascist Ideology, „Journal of Contemporary History” 1987, nr 22, s. 379-400; idem, Nascita dell'ideologia fascista, Milano 2002, s. 9-52. 
polityki ${ }^{54}$. Dla faszysty najwyższy punkt politycznej lojalności i centrum mobilizacji stanowi państwo narodowe lub rasowe, gdy dla komunisty jest nim państwo klasowe, niekoniecznie własne, narodowe (stąd idea międzynarodówki, Kominternu w Moskwie itp. $)^{55}$.

Nie mamy wątpliwości, że wynikłe z badań komparatystycznych Friedricha i Brzezińskiego cechy archetypiczne dla wszystkich systemów totalitarnych są wspólne, o ile za wskaźnik totalitaryzmu weźmiemy nie kwestie ideologiczne i pochodne temu problemowi socjologiczne badania uwarstwienia i baz społecznych dla obydwu ideologii czy też detale wynikłe z oznaczenia odmiennego podmiotu historycznego, takie jak kwestia własności prywatnej albo formy w jakiej wyraża się antyklerykalizm i antyteizm tych ideologii. Jak wskazywaliśmy przy innej okazji, bez względu na różnice ideologiczne wszystkie systemy totalitarne cechuje wspólna logika rządzenia: 1. ideologizacja państwa i polityki; 2. eliminacja tradycyjnych elit politycznych; 3 . odwoływanie się do woli ludu z pominięciem zasad parlamentaryzmu; 4. merytokracja na drodze awansu partyjnego; 5. wypieranie tradycyjnej religii przez ideologię; 6. terror prewencyjny; 7. totalna mobilizacja mas; 8. powszechna indoktrynacja; 9. kult jednostki; 10. rządy monopartii pozbawionej frakcyjności; 11. gospodarka planowa; 12. nieufność wobec korpusu oficerskiego ${ }^{56}$.

Zarówno III Rzesza, jak i Związek Radziecki epoki Stalina spełniają te wyliczone czy to przez nas powyżej, czy przez Friedricha i Brzezińskiego kilku lub kilkunastopunktowe minima totalitarne. Zresztą takich wyliczeń znajdujemy w literaturze przedmiotu wiele ${ }^{57}$. Można się oczywiście w nich spierać o szczegóły. Na przykład nie jest dla nas akceptowalny punkt piąty wyliczenia autorów Dyktatury totalitarnej $i$ autokracji, że totalitaryzm cechuje ,prawie całkowity monopol na posiadanie i używanie wszelkiej broni wojskowej”. Zapewne może to być argument przekonujący dla czytelnika amerykańskiego, któremu prawo do posiadania broni gwarantuje druga poprawka do konstytucji Stanów Zjednoczonych i które uważa za gwarancję wolności. Jednak zakazu posiadania broni czytelnik europejski nigdy nie uzna za wyznacznik systemu totalitarnego, ponieważ nie jest to, i nigdy nie było, uprawnienie uznawane w Europie za istotne.

Przyjęcie za Carlem Friedrichem i Zbigniewem Brzezińskim dychotomii państwa totalitarne vs. państwa nietotalitarne w miejsce wynikłego z działań

${ }^{54}$ H. Olszewski, O roli ideologii wroga w ksztaltowaniu się systemów totalitarnych, [w:] Totalitaryzmy XX wieku, s. 47-52.

55 M. Garcia-Pelayo, Idea de la politica, Caracas 1968, s. 10-14; C. Herrera, Carl Schmitt y el marxismo. Puntos de encuentro y de ruptura en la noción de realismo politico, „Res Publica” 1998, nr 2, s. 35-68; A. Wirsching, Vom Weltkrieg zum Bürgerkrieg? Politischer Extremismus in Deutschland und Frankreich 1918-1933/39, München 1999, s. 17-37.

56 P. Bała, A. Wielomski, Wstęp do nauki o państwie, prawie i polityce. Wybrane zagadnienia, Biała Podlaska 2011, s. 45-47.

57 Zob. na przykład F. Naumann, Notes sur la theorie de la dictature [1954], [w:] Le totalitarisme, s. 538-540; R. Aron, Démocratie et totalitarisme [1965], [w:] Le totalitarisme, s. 488-502; T. Todorov, op. cit., s. 782; J. Linz, Totalitarian and authoritarian..., s. 70. 
wojennych podziału na państwa faszystowskie i antyfaszystowskie rzeczywiście stanowi posunięcie rewolucyjne. Zapewne formuła ta jest nadużywana przez Niemców i Japończyków, którzy tak chętnie lubią mówić, że dokonali rozliczenia z totalitarną przeszłością, a więc jako państwa liberalno-demokratyczne nie mają nic wspólnego ze zbrodniami dokonanymi przez swoich ojców i dziadków. Nadużywając dyskursu o totalitaryzmie Niemcy sami zaczęli uważać się za jego ofiary i przestali się postrzegać jako sprawcy. Dokonali samorozgrzeszenia swoich win, a odpowiedzialność za nazizm z Niemiec i Niemców przenieśli na jakieś abstrakcyjne pojęcie totalitaryzmu i totalitarystów, tak jakby były to istoty pozbawione przynależności narodowej i mówiące w kosmopolitycznym esperanto ${ }^{58}$. Co więcej, zaczęli nawet pouczać innych jak należy walczyć z neonazizmem. Postawa ta często przyjmowana jest w Polsce ironicznie, gdyż stanowi intelektualne nadużycie. Nie zmienia to jednak faktu, że podział na faszystów i antyfaszystów w warunkach zimnej wojny rzeczywiście stał się anachroniczny, nie odzwierciedlając rzeczywistości nie tylko politycznej, ale i instytucjonalnej.

\subsection{Kwestia fundamentalna 2: totalitaryzm a autorytaryzm}

Po 1945 roku rzeczywiście znaleźliśmy się w sytuacji, gdy — patrząc na rzecz politologicznie z punktu widzenia tak zwanego typu państwa - mieliśmy podział istniejących państw na komunistyczne (w języku Friedricha i Brzezińskiego: totalitarne), autorytarne i liberalne. Te pierwsze charakteryzują się omnipotencją państwa wobec społeczeństwa i monopolem dyktatorów na decyzje polityczne; te drugie monopolizują tylko sferę polityczną, bardziej lub mniej szanując autonomię życia społecznego i ekonomicznego; te ostatnie uznają partycypację społeczną w procedurze wyboru władzy i pewną autonomię sfery społeczno-ekonomicznej.

Dyktatury łączy z totalitaryzmem jednoosobowa, nieograniczona władza oraz istnienie monopartii. Jednak pod tymi samymi nazwami kryją się odmienne treści ${ }^{59}$. W systemach autorytarnych dyktator może być przedstawiany jako ojciec narodu albo mąż stanu, ale jest człowiekiem, a nie półbogiem czy arcykapłanem sprawującym władzę sakralną, ponieważ autorytaryzmy nie są zideologizowane i nie mają aspiracji, aby tradycyjną religię zastępować tym, co krytycy totalitaryzmów nazwali ,liturgią polityczną" lub „religią polityczną,"60, ewentualnie ,gnozą

58 E. Traverso, op. cit., s. 89-90.

59 Zob. na przykład P. Brooker, Non-Democratic Regimes. Theory, Government and Politics, London 2000, s. 8-58, 116-128; J. Linz, Totalitarian and authoritarian...; M. Bankowicz, Niedemokratyzmy, Kraków 2011, s. 11-52. Znakomitą ogólną charakterystykę konserwatywnego autorytaryzmu jako typu państwa daje A. Siaroff, Les États autoritaires en Europe, 1919-1945, Toronto 2009, s. 10-128.

60 E. Voegelin, Die Politischen Religionen, München 2007 [1938]; R. Aron, L'âge des empires et l'avenir de la France, Paris 1946, s. 287-318; J.-P. Sironneau, Sécularisation et religions 
polityczną"61. Również monopartie totalitarne i autorytarne mają inny charakter. W tych pierwszych zdelegalizowana jest frakcyjność, czyli odmienność organizacyjno-doktrynalna. Oczywiście także i tutaj mamy spory rozmaitych koterii o przywództwo lub dostęp do ucha wodza, ale to spory personalne, a nie ideowe, gdyż monopol ideotwórczy miał nieomylny wódz. Tymczasem partie autorytarne łączy szacunek dla dyktatora i kilka ogólnych haseł. Dyktatury prawicowe to rodzaj federacji rozmaitych sił politycznych od centrum po skrajną prawicę, a lewicowe to podobna federacja, tyle, że od centrum po skrajną lewicę ${ }^{62}$. Zupełnie różny jest też zakres kontroli społeczeństwa przez władzę w dyktaturze autorytarnej i totalitarnej.

Dlatego w pełni zgadzamy się z tezą, że systemy autorytarne winny być wyodrębnienie od totalitarnych, włącznie z kluczowym dla autorów Dyktatury totalitarnej i autokracji przypadkiem Hiszpanii, którą chcą oni obronić przed zarzutem faszyzmu, ponieważ znajdowała się w sojuszu wojskowym ze Stanami Zjednoczonymi. Nawet jeśli byłoby prawdą, że impulsem do tego wyodrębnienia jest racja stricte polityczna, to nie zmienia to faktu, że jest to posunięcie słuszne z punktu widzenia politologa, czemu dawaliśmy już wyraz w naszych pracach dotyczących państwa generała Franco ${ }^{63}$. Widać to szczególnie przy problemie limitowanego pluralizmu w postaci rządzącej tym państwem monopartii, która była zaiste federacją środowisk chadeckich, prawicowo-liberalnych, nacjonalistycznych, karlistowskich, katolickich, aż po faszyzujących falangistów ${ }^{64}$.

politiques, La Haye 1982, s. 205-556. W najnowszej literaturze przede wszystkim prace E. Gentile: Il culto del littorio. La sacralizzazione della politica nell'Italia fascista, Roma 1998; Qu'est-ce que le fascisme? Histoire et interprétation, Paris 2004, s. 313-353; Les religions de la politique, Paris 2005, s. 105-142.

61 A. Besançon, Les Origines intellectuelles du léninisme, Paris 1977; idem, El marxismo, ¿Ciencia, Ideología, Gnosis?, „Espíritu” 1986, nr 93, s. 55-62; E. Voegelin, Nowa nauka polityki, Warszawa 1992 [1952], s. 103-124; idem, Od Oświecenia do Rewolucji, Warszawa 2011 [1975], s. 325-406; R. Bäcker, Gnoza polityczna systemu totalitarnego, [w:] Skryte oblicze systemu komunistycznego. U źródet zła, red. R. Bäcker, P. Hübner, Warszawa 1997, s. 5-14; R. Bäcker, Totalitaryzm w Polsce lat 1948-1956, „Czasy Nowożytne” 6, 1999, s. 10-11.

62 G. Hermet, Les fonctions politiques des organisations réligieuses dans les régimes à pluralisme limité, „Revue Française de Science Politique” 22, 1973, z. 3, s. 439-472; J.-F. Sirinelli, Les droites françaises. De la Révolution à nos jours, Paris 1992, s. 564-570.

${ }^{63} \mathrm{Na}$ temat naszej oceny Hiszpanii frankistowskiej w tej kwestii zob. A. Wielomski, Hiszpania Franco. Źródła i istota doktryny politycznej, Biała Podlaska 2006, s. 309-315; idem, Prawica w XX wieku, Radzymin 2013, s. 255-274. Na temat naszej oceny autorytaryzmu jako oddzielnego typu państwa zob. idem, Ogólna teoria autorytaryzmu na tle klasyfikacji systemów politycznych, [w:] Białoruś - co tam się dzieje? Sytuacja polityczna na przełomie XX i XXI wieku, red. A. Wielomski, A. Meller, J. Rak, Warszawa 2013, s. 11-42.

64 J. Linz, From Falange to Movimiento: The Role of a Single Party in an Authoritarian Regime, [w:] Authoritarian Politics in Modern Society, red. S. Huntington, C.H. Moore, New York 1970, s. 128-203; A. Miguel, Sociologia del Franquismo, Barcelona 1975, s. 143-236. 


\subsection{Błędy i zastrzeżenia}

Doceniając twórczy wkład Carla Friedricha i Zbigniewa Brzezińskiego do nauk o polityce, nie sposób także nie wskazać pewnych błędów i kwestii wątpliwych pojawiających się na łamach Dyktatury totalitarnej i autokracji. Po części wynikają one z ówczesnej niedostatecznej wiedzy o totalitaryzmach, jaką mieli badacze w połowie lat pięćdziesiątych XX wieku, po części zaś, jak się wydaje, z lektur fałszujących rzeczywistość państw tego typu.

Najpoważniejszym zarzutem jest błędna, w naszym przekonaniu, analiza podmiotu rządzącego w państwach tego typu. W całej pracy Friedricha i Brzezińskiego przewija się teza, że za ideologią totalitarną, rewolucją bolszewicką lub faszystowską, figurą sakralizowanego wodza kryją się rządy bezosobowej biurokracji, złożonej z ludzi aparatu partyjnego, którzy w wyniku rewolucji zdobyli dostęp do urzędów różnego szczebla, a dzięki wszechobecnemu terrorowi, omnipotencji państwa i planowaniu gospodarczemu liczba biurokratów uległa wielokrotnemu pomnożeniu w stosunku do rzeczywistości przedtotalitarnej. W skład rządzącej biurokracji wchodzą biurokraci z urzędów centralnych, pseudosamorządowych, kierujący gospodarką, personel menedżerski państwowych firm i kołchozów (dotyczy tylko państw komunistycznych), dyrektorzy szkół, redaktorzy naczelni mediów itp. ${ }^{65}$

Z powyższej tezy wynika, że Mussolini, Hitler, Lenin, Stalin, Mao i Bierut mieli $\mathrm{w}$ teorii władzę nieograniczoną, ale faktycznie państwem kierowała biurokracja, której strategiczne decyzje wymykały się kontroli wodza. Faktycznie możemy spotkać w literaturze znaczące kontrowersje dotyczące na przykład rzeczywistego zakresu kontroli tego, co działo się w III Rzeszy przez Hitlera — od poglądów, że wiedział wszystko, po myśl, że nie bardzo panował nad państwem i, izolowany przez otoczenie, nie był świadomy tego, co się dzieje ${ }^{66}$. Rewizjoniści historyczni doprowadzają tę tezę do absurdu, dowodząc, że mógł nawet nie wiedzieć o Holocauście ${ }^{67}$. Nam jednak poglądy tego typu wydają się fałszywe, ponieważ zapomina się, że Hitler często wydawał rozkazy ustnie lub przez telefon i nie zostały po nich namacalne ślady. W odróżnieniu od woluntaryzmu nazistów, komuniści prowadzili iście bizantyjskie archiwa i dlatego nie mamy wątpliwości, że Stalin całkowicie panował nad sytuacją w ZSRR i konsekwentnie wzmacniał swoją władzę, aż do stanu swoistej omnipotencji, dobrze zdając sobie sprawę z popełnianych zbrodni. Jest oczywiste, że — jak wszyscy politycy — przywódcy totalitarni panowali za pomocą biurokracji i nie wiedzieli o wszystkich jej poczynaniach, o każdej decyzji administracyjnej czy bezprawnym aresztowaniu. Jednakże pogląd, że biurokracja wyemancypowała się spod ich władzy jest bezzasadny. Gdyby tak było, to Stalin nie mógłby raz za razem przeprowadzać

65 C.J. Friedrich, Z. Brzeziński, op. cit., passim, zwłaszcza s. 45-60, 205-212.

66 Stan dyskusji na ten temat przedstawia I. Kershaw, Qu'est-ce que le..., s. 127-162.

67 M. Karas, Filozoficzne podstawy neonazizmu, „Pro Fide Rege et Lege” 2018, nr 79, s. 297. 
kolejnych czystek obejmujących nie tylko biurokrację, ale także i aparat represji. Zgadzamy się więc z tymi badaczami, którzy uznają władzę Hitlera i Stalina za jak najbardziej realną ${ }^{68}$.

Z powodu upadku państw faszystowskich w wyniku II wojny światowej nie możemy opisać ich losów po śmierci ojców-założycieli, czyli Mussoliniego i Hitlera. Mamy za to obszerny materiał do badania totalitaryzmów komunistycznych w ZSRR i bloku wschodnim po śmierci Stalina (1953), gdy zaczęła się epoka destalinizacji ogłoszona przez Nikitę Chruszczowa (1956). KPZR nie miała już charyzmatycznego przywódcy, zelżał terror, wypuszczono z więzień i gułagów miliony ludzi. Epokę tę charakteryzuje już brak wiary w rewolucję, stworzenie nowego człowieka i nowego świata. Zarzucono projekt tego, co Emilio Gentile określa mianem „rewolucji antropologicznej”69. Chruszczow i jego następcy administrują Związkiem Radzieckim i jego sferą wpływów, w zasadzie broniąc istniejącego status quo. Rewolucja instytucjonalizuje się i staje się poniekąd konserwatywna (w rozumieniu obrony tego, co zastane). Po 1956 roku podmiotem rządzącym rzeczywiście staje się partia, konkretnie jej Biuro Polityczne, a w terenie rozrastająca się partyjno-państwowa biurokracja, szukająca wygodnego życia, awansu, talonów na samochody, mieszkań z przydziału i wczasów na Krymie. To panowanie biurokratyczne, gdzie ideologia przeistoczyła się w slogany, Juan Linz określa mianem ,posttotalitaryzmu"70, negując pogląd o totalitarnym charakterze ZSRR czy PRL po 1956 roku. Dodajmy, że jest to teza na świecie dawno przyjęta, ale wywołująca znaczne kontrowersje w nauce polskiej, gdzie na tezy politologiczne i prawne wpływają poglądy polityczne badaczy, które w Polsce częstokroć warunkowane są emocjonalnym stosunkiem do PRL-u ${ }^{71}$.

Skąd błędna teza o panowaniu biurokracji, a nie charyzmatycznych przywódców, znalazła się w Dyktaturze totalitarnej i autokracji, wydanej w 1956 roku, czyli napisanej przed słynnym referatem Chruszczowa? Dość długo zastanawialiśmy się nad tym problemem, aby ostatecznie dojść do wniosku, że wskazówką może być to, że żaden z autorów tej pracy nigdy nie żył i nie mieszkał w państwie totalitarnym. Brzeziński wyjechał do Kanady w wieku 11 lat, w 1938 ro-

68 I. Kershaw, Retour sur le..., s. 867-868; N. Werth, Totalitarisme ou révisionnisme? L'histoire soviétique, un histoire en chantier, „Communisme” 1996, nr 47-48, s. 57-70.

69 E. Gentile, Qu'est-ce que le..., s. 354-395; idem, 'L'homme nouveaux' du fascisme. Réflexions sur une expérience de révolution antropologique, [w:] L'homme nouveau dans l'Europe fasciste (1922-1945). Entre dictature et totalitarisme, red. M.-A. Metard-Bonucci, P. Milza, Paris 2004, s. 35-63.

70 J. Linz, Totalitarian and authoritarian..., s. 3-7, 245-261. Podobny pogląd przedstawiają na przykład C. Castoradis, Les destinées du totalitarisme [1981], [w:] Le totalitarisme, s. 731-748; I. Kershaw, Retour sur le..., s. 854-859.

71 Jej zwolennikiem jest na przykład L. Mażewski, Posttotalitarny autorytaryzm PRL 19561989. Analiza ustrojowopolityczna, Warszawa 2010. Tezę o ciągłości totalitarnej przed i po 1956 roku głoszą między innymi J. Staniszkis, Samoograniczająca się rewolucja, Gdańsk 2010, s. 177192; R. Legutko, Esej o duszy polskiej, Warszawa 2009, s. 42 n. 
ku, a Friedrich wyemigrował do Stanów Zjednoczonych w 1925 roku, zaraz po studiach. Stąd ich znajomość totalitaryzmu była z drugiej ręki, ułatwiona przez fakt, że perfekcyjnie znali języki państw rządzonych w ten sposób. Ich badania nad totalitaryzmem wynikały przeto nie $\mathrm{z}$ własnych obserwacji i doświadczeń, lecz z rozmów z ludźmi i z lektur krytyków tych systemów, zwykle emigrantów, którzy uciekli z III Rzeszy, ZSRR i Europy Wschodniej.

Najwięcej analiz systemu stalinowskiego pisali w tym czasie na Zachodzie trockiści, uważający, że Stalin po śmierci Lenina zdradził rewolucję, między innymi dlatego, iż rządy rad zakładowych zostały zastąpione przez partyjnych menedżerów. Trockistowska utopia zakładała nie rządy partyjnych biurokratów, lecz ludu pracującego, stanowiąc radykalny program demokratyzacji zarządzania państwem, fabrykami, wspólnotami wiejskimi itp. Rządy Stalina postrzegali jako odpowiednik zamachu termidoriańskiego, gdy władza ludu została zastąpiona władzą partyjnych decydentów ${ }^{72}$. Trudno nie zauważyć, że koncepcja trockistowska, iż władza totalitarna to rządy biurokratyczne w miejsce obiecywanych przez rewolucjonistów rządów ludu, w pełni pokrywa się z główną tezą Brzezińskiego i Friedricha. Wydaje się ona stanowić podstawową inspirację dla głównej tezy ich książki. W naszym przekonaniu ta trockistowska interpretacja stała się prawdziwa dopiero od 1956 roku, czyli już po ukazaniu się Dyktatury totalitarnej i autokracji, będąc falsyfikacją istoty systemów totalitarnych znanych przed ukazaniem się tej książki.

Innymi słowy, eksploatowana przez Zbigniewa Brzezińskiego i Carla Friedricha teza trockistowska byłaby adekwatna do opisania posttotalitaryzmu, podczas gdy do hitleryzmu i stalinizmu jest nieadekwatna. Co więcej, teza trockistów ma uwarunkowanie marksistowskie: każde państwo stanowi narzędzie czyjegoś panowania klasowego. Skoro zaś bolszewicy zlikwidowali dotychczasowe klasy panujące, to zdrada rewolucji polegała na wykreowaniu nowej warstwy rządzącej w postaci biurokracji, która ukradła ZSRR klasie robotniczej i uczyniła to państwo narzędziem własnego panowania. Wpływ interpretacji trockistowskiej na politologów antykomunistycznych, którzy nigdy nie krytykowali stalinizmu z punktu widzenia marksistowskiej ortodoksji, dowodzi trafności myśli Josepha de Maistre'a, który pisał o kontrrewolucjonistach z przełomu XVIII i XX wieku, że „we wszystkich rewolucjach najlepsze głowy, nawet nienawidzące ducha rewolucyjnego, są same mniej lub więcej nim przesiąknięte, choć o tym nie wiedzą"73.

72 L. Trocki, Zdradzona rewolucja. Czym jest ZSRR i dokąd zmierza?, Pruszków 1991 [1936], s. 69-109, 175-188, 204-212; idem, L'URSS dans la guerre [1939], [w:] Le totalitarisme, s. 315323. Zob. też pisma trockistów: V. Serge, Lettre sur le totalitarisme stalinien [1933], [w:] Le totalitarisme, s. 278-281; J. Burnham, La révolution des organisateurs [1941], [w:] Le totalitarisme, s. $389-400$.

73 J. de Maistre, Correspondance, [w:] idem, Oeuvres Completes, Lyon 1887, t. 12, s. 409. 


\section{Bibliografia:}

Aquarone A., Fascismo e antifascismo nella storiografia italiana, Roma 1986.

Arendt H., Korzenie totalitaryzmu, Warszawa 1993 [1953], t. 1-2.

Aron R., L'âge des empires et l'avenir de la France, Paris 1946.

Aron R., Démocratie et totalitarisme [1965], [w:] Le totalitarisme. Le XX siècle en débat, red. E. Traverso, Paris 2001.

Bäcker R., Gnoza polityczna systemu totalitarnego, [w:] Skryte oblicze systemu komunistycznego. Uźródet zła, red. R. Bäcker, P. Hübner, Warszawa 1997.

Bäcker R., Totalitaryzm w Polsce lat 1948-1956, „Czasy Nowożytne” 6, 1999.

Bała P., Wielomski A., Wstęp do nauki o państwie, prawie i polityce. Wybrane zagadnienia, Biała Podlaska 2011.

Bankowicz M., Niedemokratyzmy, Kraków 2011.

Barber B.R., Spiro H.J., Counter-Ideological Uses of 'Totalitarianism', „Politics and Society” 1, 1971, nr 3.

Bauer O., Der Faschismus [1936], [w:] Faschismus und Kapitalismus, red. W. Abendroth, Wien 1967.

Besançon A., Les Origines intellectuelles du léninisme, Paris 1977.

Besançon A., El marxismo, ¿Ciencia, Ideología, Gnosis?, „Espíritu” 1986, nr 93.

Beyme K. von, A Founding Father of Comparative Politics: Carl Joachim Friedrich, [w:] Comparative European Politics. The Story of a Profession, red. H. Daalder, London 1997.

Bojenko-Izdebska E., Dwa totalitaryzmy w Niemczech — dyskusja wokół teorii porównawczej na przyktadzie oceny systemu NRD, [w:] Totalitaryzmy XX wieku. Idee, instytucje, interpretacje, red. W. Kozub-Ciembroniewicz, H. Kowalska-Stus, B. Szlachta, M. Kiwior-Filo, Kraków 2010.

Bordiga A., Stato, capitalisti e ceti medi [1922], [w:] Interpretazioni del fascismo, red. C. Casucci, Bologna 1982.

Borkenau F., The totalitarian enemy, London 1940.

Bracher K.D., Totalitarismus und Faschismus, Münich 1980.

Brooker P., Non-Democratic Regimes. Theory, Government and Politics, London 2000.

Burnham J., La révolution des organisateurs [1941], [w:] Le totalitarisme. Le XX siècle en débat, red. E. Traverso, Paris 2001.

Canovan M., The Leader of the Masses: Hannah Arendt on Totalitarianism and Dictatorship, [w:] Dictatorship in History and Theory. Bonapartism, Cesarism, and Totalitarianism, red. P. Baehr, M. Richter, Cambridge 2004.

Carver T., Marx's 'Eighteenth Brumaire of Louis Bonaparte': Democracy, Dictatorship, and the Politics of Class Struggle, [w:] Dictatorship in History and Theory. Bonapartism, Cesarism, and Totalitarianism, red. P. Baehr, M. Richter, Cambridge 2004.

Castoradis C., Les destinées du totalitarisme [1981], [w:] Le totalitarisme. Le XX siècle en débat, red. E. Traverso, Paris 2001.

Colombani J.-M., Le communisme et nous, „Le Monde“, 5.12.1997.

Costa Pinto A., The Salazar 'New State’ and European Fascism, San Domenico 1991.

Courtois S., Ernst Nolte: penser le fascisme et le totalitarisme, [w:] Fascisme et totalitarisme, red. E. Nolte, Paris 2008.

Courtois S., La tragédie communiste, „Le Monde”, 20.12.1997.

Courtois S., Zbrodnie komunizmu, [w:] Czarna księga komunizmu. Zbrodnie, terror, prześladowania, red. S. Courtois, N. Werth, J.-L. Panné, A. Paczkowski, K. Bartosek, J.-L. Margolin, Warszawa 1999 [1997].

Czarna księga komunizmu. Zbrodnie, terror, prześladowania, red. S. Courtois, N. Werth, J.-L. Panné, A. Paczkowski, K. Bartosek, J.-L. Margolin, Warszawa 1999 [1997]. 
Darmagen J.-Y., Logique du fascisme. L'Etat totalitaire en Italie, Paris 2008.

De Felice R., Mussolini, Torino 1965-1997, t. 1-8.

Ferrary Ojeda A., Los Estados Unidos y el regimen de Franco, 1945-1973, „Memoria y Civilisación” 2018, nr 21.

Flores M., Le débat italien sur le communisme entre chronique et histoire, „Matériaux por l'Histoire de notre Temps" 2002, nr 68.

Fontaine J.-M., À quoi sert le totalitarisme?, „L'Homme et la Société“ 1984, nr 71-72.

Forti S., El totalitarismo. Trayectoria de una idea límite, Barcelona 2008.

Fortshoff E., Der totale Staat, Hamburg 1933.

Friedländer S., Le nazisme: fascisme ou totalitarisme [1985], [w:] Le totalitarisme. Le XX siècle en débat, red. E. Traverso, Paris 2001.

Friedrich C.J., The unique character of totalitarian society, [w:] Totalitarianism, red. C.J. Friedrich, Cambridge 1954.

Friedrich C.J., Brzeziński Z., Totalitarian Dictatorship and Autocracy, New York 1966 [1956].

Fuentes J.F., Totalitarismo: origen y evolución de un concepto clave, „Revista de Estudios Politícos” 2006, nr 134.

Furet F., Les différents aspects du concept de totalitarisme [1996], [w:] Le totalitarisme. Le XX siècle en débat, red. E. Traverso, Paris 2001.

Furet F., Przeszłość pewnego złudzenia. Esej o idei komunistycznej w XX w., Warszawa 1996 [1995].

Garcia-Pelayo M., Idea de la politica, Caracas 1968.

Gentile E., Il culto del littorio. La sacralizzazione della politica nell'Italia fascista, Roma 1998.

Gentile E., 'L'homme nouveaux' du fascisme. Réflexions sur une expérience de révolution antropologique, [w:] L'homme nouveau dans l'Europe fasciste (1922-1945). Entre dictature et totalitarisme, red. M.-A. Metard-Bonucci, P. Milza, Paris 2004.

Gentile E., Qu'est-ce que le fascisme? Histoire et interprétation, Paris 2004.

Gentile E., Les religions de la politique, Paris 2005.

Gentile E., La silence de Hannah Arendt. L'interprétation du fascisme dans 'Les origines du totalitarisme', „Revue d'Histoire Moderne et Contemporaine” 55, 2008, nr 3.

Gentile E., La via italiana al totalitarismo, Roma 1995.

Gómez-Escalonilla L.L.D., El 'amigo americano'? España y Estados Unidos durante el franquismo, „Studia Historica” 2003, nr 21.

Guérin D., Fascisme et grand capital, Paris 1999 [1938].

Halévy E., L'Ére des tyrannies. Études sur le socialisme et la guerre, Paris 1938.

Hayes C.J.H., The Novelty of Totalitarianism in the History of Western Civilization, „Proceedings of the American Philosophical Society" 82, 1940, nr 1.

Henning F.-W., Das industrialisierte Deutschland, 1914 bis 1978, Paderborn 1979.

Hermet G., Les fonctions politiques des organisations réligieuses dans les régimes à pluralisme limité, „Revue Française de Science Politique” 22, 1973, z. 3.

Herrera C., Carl Schmitt y el marxismo. Puntos de encuentro y de ruptura en la noción de realismo politico, „Res Publica” 1998, nr 2.

Hilferding R., Capitalisme d'État ou économie d'État totalitaire [1940], [w:] Le totalitarisme. Le XX siècle en débat, red. E. Traverso, Paris 2001.

,Historikerstreit '. Die Dokumentation der Kontroverse um die Einzigartigkeit der nationalsozialistischen Judenvernichtung, red. E. Piper, München 1987.

Holzer J., System faszystowski a autorytarny. Uwagi polemiczne, „Studia nad Faszyzmem i Zbrodniami Hitlerowskimi” 3, 1977.

Hue R., La marche du siècle antistalinien jusqu'au bout, „L'Humanité”, 5.11.1997.

Jaspers K., La lutte contre le totalitarisme [1954], [w:] Le totalitarisme. Le XX siècle en débat, red. E. Traverso, Paris 2001. 
Joffrin L., Ceux qui cherchent à relativiser les crimes du communisme, chargeant Stalin seul, ne sont fidèles qu'à leurs erreuers. Sauver Lénine?, „Libération“, 17.11.1997.

Karas M., Filozoficzne podstawy neonazizmu, „Pro Fide Rege et Lege” 2018, nr 79.

Kellenbenz H., Deutsche Wirtschaftsgeschichte, t. 2, München 1981.

Kershaw I., Qu'est-ce que le nazisme? Problèmes et perspectives d'interpretation, Paris 1997.

Kershaw I., Retour sur le totalitarisme. Le nazisme et le stalinisme dans une perspective comparative [1994], [w:] Le totalitarisme. Le XX siècle en débat, red. E. Traverso, Paris 2001.

Kocka J., Geschichte und Aufklärung, Göttingen 1989.

Kohn H., Revolution and Dictatorships. Essays in contemporary history, Cambridge 1941.

Lavergne B., Les États totalitaires ou le retour de l'Europe au XVI ou XVII siècle [1937], [w:] Le totalitarisme. Le XX siècle en débat, red. E. Traverso, Paris 2001.

Lefebvre M., Werth N., Le communisme, entre analyse scientifique et vision policière de l'historie, „Le Monde”, 21.09.2000.

Lefort C., La logique totalitaire [1980], [w:] Le totalitarisme. Le XX siècle en débat, red. E. Traverso, Paris 2001.

Legutko R., Esej o duszy polskiej, Warszawa 2009.

Lietzmann H.J., Carl Joachim Friedrich (1901-1984). Leben-Werk-Wirkung, [w:] Klassiker der Politikwissenschaft, red. H.J. Lietzmann, W. Bleek, München 2005.

Linz J., From Falange to Movimiento: The Role of a Single Party in an Authoritarian Regime, [w:] Authoritarian Politics in Modern Society, red. S. Huntington, C.H. Moore, New York 1970.

Linz J., Totalitarian and authoritarian Regimes, London 2000.

Linz J., Un régimen autoritario: España, Helsinki 1964.

Maciejewski M., Hiszpański faszyzm i frankizm w polskiej literaturze politycznej i naukowej (19361997), „Studia nad Faszyzmem i Zbrodniami Hitlerowskimi” 21, 1998.

Maistre J. de, Correspondance, [w:] idem, Oeuvres Completes, t. 12, Lyon 1887.

Marcuse H., Walka z liberalizmem w totalitarnej koncepcji państwa [1934], [w:] Szkoła Frankfurc$k a$, red. J. Łoziński, t. 2, Warszawa 1985.

Marks K., Osiemnasty brumaire'a Ludwika Bonaparte [1852], [w:] K. Marks, F. Engels, Dzieła wybrane, t. 1, Warszawa 1981.

Mażewski L., Posttotalitarny autorytaryzm PRL 1956-1989. Analiza ustrojowopolityczna, Warszawa 2010.

Miguel A., Sociologia del Franquismo, Barcelona 1975.

Monnerot J., Sociologie de la révolution. Mythologies politiques du XXe siècle, Paris 1969.

Moradiellos García E., Franco y el fascismo, „Temas para el Debate” 2009, nr 172.

Naumann F., Notes sur la theorie de la dictature [1954], [w:] Le totalitarisme. Le XX siècle en débat, red. E. Traverso, Paris 2001.

Nolte E., Der europäische Bürgerkrieg 1917-1945. Nationalsozialismus und Bolschewismus, München 2000.

Nolte E., Der Faschismus in seiner Epoche. Action française, Italienischer Faschismus, Nationalsozialismus, München 1979.

Olszewski H., O roli ideologii wroga w kształtowaniu się systemów totalitarnych, [w:] Totalitaryzmy XX wieku. Idee, instytucje, interpretacje, red. W. Kozub-Ciembroniewicz, H. Kowalska-Stus, B. Szlachta, M. Kiwior-Filo, Kraków 2010.

Petersen J., La nascita del concetto di 'Stato totalitario' in Italia, „Annali dell'Istituto Storico Italo-Germanico di Trento" 1, 1975.

Pomian K., Totalitarisme, „Vingtième Siècle” 1995, nr 47.

Poulantzas N., Fascisme et dictature, b.m.w. 1974 [1970].

Preston P., Gascón D., 'Franco no era fascista. Era algo peor', „Letras Libres” 2015, nr 170.

Prochasson Ch., Le terrorisme de la vertu, [w:] Les Gauches françaises, 1762-2012. Figures et paroles, red. J. Julliard, Paris 2014. 
Redlich F., German Economic Planning for War and Peace, „The Review of Politics” 6, 1944, nr 3.

Rigoulot P., Yannakakis I., Un pavé dans l'histoire: le débat français sur Le Livre noir du communisme, Paris 1998.

Riley D., The civic foundations of fascism in Europe. Italy, Spain, and Romania, 1870-1945, Baltimore 2010.

Saage R., Faschismus. Konzeptionen und historische Kontexte, Wiesbaden 2007.

Salvemini G., Pour la liberté de l'esprit [1935], [w:] Le totalitarisme. Le XX siècle en débat, red. E. Traverso, Paris 2001.

Schleifstein J., Marxismus und Staat. Zur Entwicklung der Staatsauffassung bei dem marxistischen Klassikern, Frankfurt am Main 1982.

Schmiechen-Ackermann D., Diktaturen im Vergleich, Darmstadt 2002.

Schmitt C., Positionen und Begriffe im Kampf mit Weimar-Genf-Versailles 1923-1939, Berlin 1994 [1940].

Schöngarth M., Die Totalitarismusdiskussion in der neuen Bundesrepublik 1990 bis 1995, Köln 1996.

Serge V., Lettre sur le totalitarisme stalinien [1933], [w:] Le totalitarisme. Le XX siècle en débat, red. E. Traverso, Paris 2001.

Siaroff A., Les États autoritaires en Europe, 1919-1945, Toronto 2009.

Les siècle des communismes, Paris 2004.

Sirinelli J.-F., Les droites françaises. De la Révolution à nos jours, Paris 1992.

Sironneau J.-P., Sécularisation et religions politiques, La Haye 1982.

Skarzyński R., Od liberalizmu do totalitaryzmu, t. 2, Warszawa 2002.

Staniszkis J., Samoograniczająca się rewolucja, Gdańsk 2010.

Sternhell Z., The 'Antimaterialism Revision' of Marxism as an Aspect of the Rise of Fascist Ideology, ,Journal of Contemporary History” 1987, nr 22.

Sternhell Z., Nascita dell'ideologia fascista, Milano 2002.

Sturzo L., Morale et politique. Orientations et expérience, Paris 1938.

Sul libro nero del comunismo, Roma 1998.

Talmon J.L., Le origini della democrazia totalitaria, Bologna 2000 [1952].

Todorov T., Le totalitarisme, encore une fois [1997], [w:] Le totalitarisme. Le XX siècle en débat, red. E. Traverso, Paris 2001.

Togliatti P., Grossa e piccola borghesia [1928], [w:] Interpretazioni del fascismo, red. C. Casucci, Bologna 1982.

Traverso E., Introduction. Le totalitarisme. Jalons pour l'histoire, [w:] Le totalitarisme. Le XX siècle en débat, red. E. Traverso, Paris 2001.

Tresso P., Fascismo repressione capitalistica [1930], [w:] Interpretazioni del fascismo, red. C. Casucci, Bologna 1982.

Trocki L., L'URSS dans la guerre [1939], [w:] Le totalitarisme. Le XX siècle en débat, red. E. Traverso, Paris 2001.

Trocki L., Zdradzona rewolucja. Czym jest ZSRR i dokąd zmierza?, Pruszków 1991 [1936].

Tusell J., La dictadura de Franco, Madrid 1996.

Voegelin E., Nowa nauka polityki, Warszawa 1992 [1952].

Voegelin E., Od Oświecenia do Rewolucji, Warszawa 2011 [1975].

Voegelin E., Die Politischen Religionen, München 2007 [1938].

Werth N., Totalitarisme ou révisionnisme? L'histoire soviétique, un histoire en chantier, „Communisme" 1996, nr 47-48.

Wielomski A., Hiszpania Franco. Źródła i istota doktryny politycznej, Biała Podlaska 2006.

Wielomski A., Nacjonalizm francuski 1886-1940. Geneza, przemiany i istota filozofii politycznej, Warszawa 2007. 
Wielomski A., Ogólna teoria autorytaryzmu na tle klasyfikacji systemów politycznych, [w:] Białoruś - co tam się dzieje? Sytuacja polityczna na przełomie XX i XXI wieku, red. A Wielomski, A. Meller, J. Rak, Warszawa 2013.

Wielomski A., Prawica w XX wieku, Radzymin 2013.

Wirsching A., Vom Weltkrieg zum Bürgerkrieg? Politischer Extremismus in Deutschland und Frankreich 1918-1933/39, München 1999.

Zetkin C., Der Kampf gegen den Faschismus [1923], [w:] Theorie über den Faschismus, red. E. Nolte, Köln 1967.

Ziętek-Wielomska M., Wielomski A., Nowoczesność, Nacjonalizm, Naród Europejski. Dylematy samoidentyfikacji Europejczyków, Warszawa 2017. 